NBER WORKING PAPER SERIES

\title{
THE CROSS-SECTION OF HURDLE RATES FOR CAPITAL BUDGETING: AN EMPIRICAL ANALYSIS OF SURVEY DATA
}

\author{
Ravi Jagannathan \\ Iwan Meier \\ Vefa Tarhan \\ Working Paper 16770 \\ http://www.nber.org/papers/w16770
NATIONAL BUREAU OF ECONOMIC RESEARCH
1050 Massachusetts Avenue
Cambridge, MA 02138
February 2011

We thank Michael Fishman, Robert Korajczyk, Deborah Lucas, Robert McDonald, David Matsa, Mitchell Petersen, Artur Raviv, Ernst Schaumburg, Michael Sher, Paul Spindt, and Timothy Thompson for helpful comments. We also thank the focus group participants William A. Colaianni, James J. Cowhey, Pavel A. Dorosevich, Gaea Gomez, Art Mollenhauer, and Don Porth for their input to improve the design of the survey. This research is sponsored by the Zell Center for Risk Research and we are indebted to its Director and Dean Emeritus of the Kellogg School of Management Donald Jacobs for his support and advice. The views expressed herein are those of the authors and do not necessarily reflect the views of the National Bureau of Economic Research.

NBER working papers are circulated for discussion and comment purposes. They have not been peerreviewed or been subject to the review by the NBER Board of Directors that accompanies official NBER publications.

(C) 2011 by Ravi Jagannathan, Iwan Meier, and Vefa Tarhan. All rights reserved. Short sections of text, not to exceed two paragraphs, may be quoted without explicit permission provided that full credit, including (C) notice, is given to the source. 
The Cross-Section of Hurdle Rates for Capital Budgeting: An Empirical Analysis of Survey

Data

Ravi Jagannathan, Iwan Meier, and Vefa Tarhan

NBER Working Paper No. 16770

February 2011

JEL No. G12,G3,G31

\begin{abstract}
Whereas Poterba and Summers (1995) find that firms use hurdle rates that are unrelated to their CAPM betas, Graham and Harvey (2001) find that $74 \%$ of their survey firms use the CAPM for capital budgeting. We provide an explanation for these two apparently contradictory conclusions. We find that firms behave as though they add a hurdle premium to their CAPM based cost of capital. Following McDonald and Siegel (1986), we argue that the hurdle premium depends on the value of the option to defer investments. While CAPM explains only $10 \%$ of the cross-sectional variation in hurdle rates across firms, variables that proxy for the benefits from the option to wait for potentially better investment opportunities explain $35 \%$. Estimates of our hurdle premium model parameters imply an equity premium of $3.8 \%$ per year, a figure that is essentially the same as that reported in the survey by Graham and Harvey (2005). Consistent with our model, growth firms use a higher hurdle rate when compared to value firms, even though they have a lower cost of capital.
\end{abstract}

\author{
Ravi Jagannathan \\ Vefa Tarhan \\ Kellogg Graduate School of Management \\ Loyola University Chicago \\ Northwestern University \\ Graduate School of Business \\ 2001 Sheridan Road \\ Leverone/Anderson Complex \\ 1 E. Pearson St., Maguire Hall \\ Chicago, IL 60611 \\ Evanston, IL 60208-2001 \\ v-tarhan@luc.edu \\ and NBER \\ rjaganna@northwestern.edu \\ Iwan Meier \\ HEC Montreal \\ 3000, chemin de la Cote-Sainte-Catherine \\ Montreal (Quebec) H3T 2A7 \\ Canada \\ iwan.meier@hec.ca
}




\section{Introduction}

According to a survey by Womack and Zhang (2005) 38\% of the total class time of the core finance courses at major MBA programs is devoted to capital budgeting decisions, computing net present value (NPV) and cost of capital. The tuition fees of the top 30 ranked MBA programs by Business Week total 1.6 billion in 2010. Thus, it appears that business schools generate considerable revenues in return for an education of the principles of corporate finance.

A number of studies document that when computing the net present value of a project, the majority of firms discount future cash flows using hurdle rates that reflect their weighted average cost of capital (WACC) (e.g. Bierman (1993), Bruner, Eades, Harris, and Higgins (1998)) and thus indeed follow the standard approach as taught in MBA programs. Additionally, surveys over the past four decades report that since Sharpe (1964) and Lintner (1965) introduced the capital asset pricing model (CAPM), firms have increasingly adopted its framework to determine their cost of equity. In fact, Graham and Harvey (2001) find that three out of four CFOs rely on the CAPM. Thus, in spite of its criticism in the literature, it appears that CAPM is widely used in practice.

In a survey that we conducted, we ask firms what they use for hurdle rates in their capital budgeting decisions. Since we know the identity of the respondents to our survey, we can match firms with fundamental Barra betas and data from Compustat and CRSP to compute their WACC. We document that hurdle rates firms use in practice exceed their computed WACC, i.e., firms add a hurdle premium to their cost of capital. ${ }^{2}$ The hurdle premium is substantial and

\footnotetext{
${ }^{2}$ In a roundtable discussion on capital structure and payout policy, Jon Anda from the investment banking division of Morgan Stanley states that "my feeling is that a large number of companies today are using hurdle rates that are well above their weighted average cost of capital” (see Smith, Ikenberry, Nayar,
} 
accounts, on average, for about half of the hurdle rate. We also find that the presence of the hurdle rate premium is independent of whether the cost of equity is inferred from the singlefactor CAPM, the Fama-French three-factor model, or computed by making assumptions about the size of the equity premium.

Poterba and Summers (1995) also find hurdle rates to be on the high side. They document an average real hurdle rate of $12.2 \%$, at a time when the long-term inflation expectation was around 5\%. They argue that the hurdle rates are higher than both the cost of debt and the cost of equity of firms in their survey sample. Moreover, they find that hurdle rates are not related to CAPM betas. How is it that firms claim to use CAPM and WACC, and yet their hurdle rates are not systematically related to beta, and are also much higher than firms' computed WACC? In this paper, we provide an explanation based on high growth prospects that make options to wait for better investment opportunities valuable when firms cannot undertake all positive net present value projects due to limited availability of organization capital. We propose a model that explains the determinants of hurdle rates and at the same time produces results that are consistent with the previous survey findings that firms indeed use CAPM and WACC. While WACC is an important determinant of the hurdle rate, it is not its only component.

The key to our model is that firms with high growth opportunities incorporate a premium associated with an option to wait to their hurdle rates. This insight is provided by McDonald and Siegel (1986). In addressing the investment timing problem they observe that investing in a current positive NPV project is irreversible, while the decision to defer the investment is reversible. They argue that the correct decision is reached by comparing the NPV of the current project with the NPV (as of the current period) that can be obtained if the investment is made in

Anda and McVey (2005, p. 52)). Additionally, Antill and Arnott (2004) claim that the hurdle rates of the twelve oil companies they examine exceed their WACC. 
the future. This option to wait is valuable to growth firms since it may enable them to take future projects that possibly have higher NPVs than the (positive) NPV projects they have in the current period. Such firms may behave in this manner due to managerial and other human capital constraints in the current period. At the same time, these firms may fear facing adverse conditions in capital markets in the future when highly valuable projects materialize. We hypothesize that in order to avoid this possibility, in the current period these firms would put themselves in a financial position to undertake the highly valuable projects that they may encounter in the future. In other words, current period financial flexibility concerns are likely to be important for firms with high growth prospects. This suggests that firms with high cash reserves would have high hurdle premia.

It is important to emphasize that the option to wait for future projects that have higher expected values than the current period positive NPV investments, is different from a traditional real option attached to a specific project. If firms consider a project to be strategic, then they judge that investing in such a project has the potential to generate additional future cash flows that are currently not incorporated in the valuation of the project. For instance, the first investment in a foreign country might pave the way for other positive NPV projects in the future. In such cases, firms could use decision trees to incorporate future cash flows. However, survey evidence shows that firms often incorporate such real options associated with strategic projects by using lower hurdle rates (e.g. Bruner, Eades, Harris, and Higgins (1998)). In contrast, firms that are in a position to take advantage of options to wait would use higher discount rates in screening projects in the current period. When firms uncover a new positive NPV project, they have to decide whether to take it or to wait for a potentially better future opportunity. The decision can be characterized as an optimal stopping problem. Given a number of future projects 
with a distribution of NPVs, where only the approximate distribution is known, the firm has to decide whether it is optimal to take a currently available positive NPV project or to wait for a better opportunity. The average expected NPV of the future projects depends on the growth prospects of the industry, while the dispersion is driven by the riskiness of the industry. This suggests that both recent period industry returns and the unpredicted fraction of industry returns would be positively correlated with hurdle premia.

If firms do not face any constraints and capital markets are well functioning, every positive NPV project in the current period would be funded. However, firms with high-growth prospects may not want to take every positive NPV project in the current period since they may find even better opportunities in the future. For this reason, firms with high growth prospects may pass up on some good current period projects by using hurdle rates that exceed their WACC. The difference between the hurdle rates they use and their computed WACC would represent the premium associated with the option to wait. The option to wait is more valuable to firms with high growth prospects who operate in an environment where the NPV distribution of possible projects are likely to have a wider dispersion than those faced by mature firms.

Jagannathan and Meier (2002) argue that organizational and managerial constraints may represent another reason why firms with valuable options to wait, i.e., firms with ample growth opportunities, would use higher hurdle rates. Since in corporate finance growth is about the sales variable, we use sales growth per employee as a proxy to measure the presence of managerial constraints. Jagannathan and Meier (2002) use a real options framework that builds on McDonald (1999) to demonstrate that depending on growth prospects and the dispersion of the NPV distribution of future projects, the hurdle rate premium can be substantial. The optimal 
solution for when to take a positive NPV project can be found using the classical stopping problem (also known as parking or secretary problem).

In this paper we make several contributions. First, we document that there is a hurdle rate premium. Second, we develop a model where hurdle rates have two components: WACC, and variables that represent firm characteristics that proxy for the value of the option to wait. The model enables us to estimate the equity premium, along with the loadings on firm characteristics. Our estimate for the equity premium is identical to the figure found by Graham and Harvey (2005) from a survey they conducted at about the same date of our survey (3.8\% in both cases). Also, unlike Poterba and Summers (1995) who do not find a significant relation between historical beta and hurdle rates, we find that fundamental beta is positively correlated with hurdle rates in our sample. Third, we find that actual WACC constitutes about half of the value of the average hurdle rate, while the remaining half of the variation in hurdle rates can be explained by variables that proxy for the value of options to wait. Furthermore, we find that dispersion of hurdle premia is three times the dispersion of WACC. Fourth, as hypothesized, financial flexibility considerations play an important role: firms with high levels of cash use higher hurdle rates. Fifth, we find that firms with high growth opportunities use higher hurdle rates (they load negatively on the Fama-French HML factor) even though their stocks earn lower returns. Additionally, the R-square obtained from the estimation of the market model for firms that are in the same industry (2 digit SIC) as the sample firms, is negatively correlated with hurdle rates. Finally, we confirm Jagannathan and Meier (2002) that managerial and organizational constraints play an important role in investment decisions: the estimate for the sales growth per employee variable is positive and is significantly related to hurdle rates. 
The remainder of the paper proceeds as follows. Section II describes the experimental design and data. Section III discusses survey results. Section IV presents the model. Empirical findings are discussed in Section V. Finally, Section VI concludes.

\section{Experimental Design and Data}

Figure 1 gives an overview of the results from the survey literature. Apparently, starting in the 1990s an overwhelming fraction of firms use discounted cash flow (DCF) methods. Similarly, starting in the 1980s the use of WACC and CAPM has increased dramatically. Interestingly, the use of company-wide hurdle rates has not declined over time. In order to examine how hurdle rates are related to cost of capital and to test whether the hurdle premium is related to options to wait, we combine survey questions with archival data from Barra, CRSP, and Compustat. Hurdle rates cannot be observed directly in archival databases and require a survey. Besides Poterba and Summers (1995), to the best of our knowledge, ours is the only survey on hurdle rates that knows the identity of the respondents. Combining survey data with financial databases enables us to examine the determinants of the hurdle premium.

The survey was completed by the CFOs of 127 companies in October 2003. A high percentage of the respondents reveal their identity (83.5\%). Almost all surveys are filled out completely and there is no decline in the number of responses towards the end of the four-page questionnaire. Survey data has strengths and weaknesses. Surveys are the only way to obtain hurdle rates used in practice. On the downside, surveys do not produce as many observations as databases such as Compustat. Additionally, if survey questions are not phrased carefully, tests based on survey responses could be misleading. In designing the survey, we carefully followed 
the advice of experts in the fields of psychology and marketing. ${ }^{3}$ We designed the questions in such a way that we minimize the use of technical terms and names of models that are taught in a typical MBA course. For example, we avoid terms such as "cost of capital" and "CAPM" in our questionnaire. Instead, the survey participants were asked questions on their "hurdle rates." It is a well documented observation in psychology, known as the social desirability hypothesis (see e.g. Singer and Presser (1989)), that respondents to surveys tend to try to please the conductor of the survey by providing the answers they think the survey's author expects. Therefore, in designing the survey questions we tried to avoid using technical terms. The input from numerous finance academics helped to further improve the content of the questions. Additionally, in order to test the survey with practitioners, we invited six CFOs from the Chicago area to a focus group meeting. After filling out the survey, we discussed each question to assure that the wording was not ambiguous. The survey was sent out together with a cover letter from the Dean Emeritus of the Kellogg School of Management, Donald Jacobs, along with a postagepaid return envelope to a total of 4,600 CFOs of U.S. companies listed in the Compustat name file. We asked the participants to return the questionnaire within ten days. A week after the initial mailing we sent a follow-up mailing to remind the potential participants.

We have some evidence that the surveys were actually filled out by CFOs as we received a number of e-mails from the CFOs requesting an advance copy of the survey results. In addition, many respondents provided elaborate comments to open questions. The survey responses appear to be accurate. For example, when we compare self-reported sales figures with the numbers retrieved from Compustat, we find that a reassuring 92.3\% of the respondents checked the correct sales range.

\footnotetext{
${ }^{3}$ Among others, Gillman (2000) and Morgan (1988) provide guidelines for surveys and focus group meetings.
} 
Table I compares the breakdown by industry, hurdle rate statistics, and the use of CAPM/WACC to previous surveys. Except for the fact that our sample excludes financial firms, the distribution across industries are comparable to other surveys. ${ }^{4}$ In all surveys and in the Compustat sample manufacturing exceeds $50 \%$ of the sample. In our survey manufacturing firms make up $66 \%$ of the sample. ${ }^{5}$ Firms in the wholesale and retail sectors make-up $11.6 \%$ of our sample, while mining and construction and transportation/communication sectors are equally represented (10.7\% each). In Table I, in the Compustat sample we compute the weights by including only the sectors that we have mailed our survey to. While our sample size is a third of Graham and Harvey (2001), we know the identity of 106 out of 127 firms and are able to match 93 firms with Barra and CRSP/Compustat. Summary statistics of the hurdle rates in our survey match those of Poterba and Summers (1995), and the use of WACC is comparable to Bruner, Eades, Harris and Higgins (1998). Other characteristics (not reported in the table) of survey firms are as follows: Firm size measured by (self-reported) sales is below $\$ 100$ million for 35.2\% of the companies and $31.2 \%$ of the responding firms report sales in excess of $\$ 1$ billion. The majority of the firms (72.0\%) have multiple product lines.

Table II compares the characteristics of the 93 responding firms for which we can match Compustat data and the Compustat sample of firms. Based on mean values it appears that the two samples are similar except for four variables. Survey firms have higher market value of

\footnotetext{
${ }^{4}$ Financial firms account for $15 \%$ of the respondents in Graham and Harvey (2001). We exclude all finance and insurance companies with the major SIC code in the ranges 6000-6499, 6700-6799; and utilities (4900-4999) in order to exclude regulated firms. We also discard radio and TV broadcasting, cable, and other pay TV services (4840-4949), as these firms might be driven by non-commercial interests, e.g. religious radio stations. Finally, we exclude health, education, social services, and museums (7200+).

${ }^{5}$ In a number of surveys the fraction of manufacturing firms is even more pronounced. For example, in Gitman and Mercurio (1982) this ratio is 93.8\%, while in Gitman and Forrester (1977) it is 74\%.
} 
assets (even though the mean book values are not statistically different). ${ }^{6}$ They also have a higher ratio of cash-to-book assets. The book assets of survey firms also generate higher operating profits. Finally, the survey firms are more capital expenditure intensive. Given that manufacturing firms are somewhat overrepresented in the survey sample, this is not surprising. Other important financial variables, such as, leverage ratio (total debt divided by book value of assets), current ratio, total asset turnover, and return on book equity are comparable.

\section{Survey Findings}

Since Poterba and Summers (1995) is the only other study where the identity of survey firms are known, it is useful to compare their findings with ours. They comment that hurdle rates in their sample appear to be too high compared to cost of capital. We confirm this observation for our survey sample. As can be seen in Panel B of Table I, while our average nominal hurdle rate of $14.8 \%$ is somewhat lower than their implied nominal rate of $17.8 \%$ (12.2\% real and inflation expectation of 5\%), their median rate that we construct from their data is $10 \%$ in real terms and $15.5 \%$ in nominal terms, which is very close to our median of $15 \%$. The standard deviations of the two samples are also similar. Taken together, these stylized facts suggest that, the real discount rates used by firms have not changed much even though the two surveys were conducted 14 years apart.

As we discussed in Section I, Poterba and Summers (1995) find no relation between hurdle rates and systematic risk as measured by historical betas. This is puzzling since it appears to contradict the evidence from the survey literature that firms use CAPM along with WACC to

\footnotetext{
${ }^{6}$ For variable definitions, see the caption of Table II.
} 
compute cost of equity and cost of capital. ${ }^{7}$ For this reason, we repeat the exercise of Poterba and Summers (1995) for our sample by regressing self-reported hurdle rates on the same set of financial variables they use. Figure 2 illustrates the results from kernel-weighted local polynomial regressions for our sample firms. We use a non-parametric kernel method to minimize the effect of outliers and to account for the presence of non-linearities. The figures suggest that the relation between hurdle rates and all the explanatory variables, except for the current ratio, are essentially flat. Even in the case of the current ratio, it appears that the relationship is dominated by some firms which have high current ratios and high hurdle rates.

Table III summarizes the bivariate OLS coefficients for the same set of explanatory variables using the two survey samples in question. The table indicates that the similarity between the two surveys extends beyond having similar summary statistics: The regression coefficients obtained from the two samples are also comparable. In neither of the samples the explanatory financial variables, except for current ratio, is related to hurdle rates. ${ }^{8}$ In our sample, even the current ratio turns out to be insignificant ( $p$-value of 0.12 ) once the two firms with current ratios in excess of 10 (the cutoff rate as e.g., in Cleary (1999)) are excluded from the analysis. Using fundamental beta from Barra instead of historical beta (estimated from five years of monthly data) slightly increases the coefficient estimates for both the full sample and manufacturing sector sub samples. In the case of manufacturing firms, the positive relationship between fundamental beta and hurdle rates cannot be rejected at the $10 \%$ level. Given that

\footnotetext{
${ }^{7}$ Graham and Harvey (2001) find that three out of four CFOs use CAPM and 85\% of the firms that Bruner, Eades, Harris, and Higgins (1998) interview use WACC.

${ }^{8}$ The coefficients for total equity return have the same sign as in Poterba and Summers (1995) but differ in size. Over the 10 years preceding the survey date (1993-2003) the S\&P 500 index increased by 138\%, whereas over the period 1980-1990 considered in Poterba and Summers (1995) the index increased by $227.4 \%$.
} 
historical beta coefficients for individual firms from an index model tend to have low R-squares, and hence provide noisy estimates, in the remainder of this paper we rely on fundamental betas.

The bar chart in Panel A of Figure 3 shows what survey participants use as their hurdle rate. Of the 117 firms that responded to the question on what their hurdle rate represents, a significant percentage of the CFOs (71.8\%) claim that the hurdle rate they use is their weighted average cost of capital (WACC). In the case of 7 firms (6.0\%), the hurdle rate represents their cost of levered equity, while for 9 firms (7.7\%) it reflects their unlevered cost of equity. For 17 firms (14.5\%), the hurdle rate falls into the "other" category. ${ }^{9}$ The widespread use of WACC in our sample is consistent with the findings of Gitman and Vandenberg (2000), Bruner, Eades, Harris, and Higgins (1998), and Bierman (1993) who report that even larger fractions of firms use WACC. As displayed in Figure 1, similar to the increased use of discounted cash flow (DCF) techniques and CAPM, the use of WACC has also increased over time. For example, in a survey conducted 30 years ago, Petty, Scott, and Bird (1975) document that only 30\% of the Fortune 500 firms that responded to their survey use WACC. In contrast, in later surveys, such as the one by Bruner, Eades, Harris, and Higgins (1998), this figure is over $80 \%$.

In the survey, we ask the participants for the nominal hurdle rate that they have used for a typical project during the two years preceding the survey date. Since hurdle rates represent firms' WACC by a substantial margin, in the case of the small number of firms which use their levered or unlevered cost of equity, we convert their hurdle rates to their WACC equivalents. In doing this, we use data on debt/asset ratios and tax rates from Compustat, and cost of debt information we obtain from the survey responses. The details of how we convert the 16 levered/unlevered cost equity responses to their WACC equivalents are described in the

\footnotetext{
${ }^{9}$ This category consists of firms which provide their hurdle rates without indicating what they represent.
} 
Appendix. Panel B of Figure 3 displays the distribution of hurdle rates (WACC and its equivalents sample) used by survey firms.

Panel A of Table IV displays summary statistics on self-reported hurdle rates for various samples: The sample of firms which indicated what their hurdle rates are (all respondents), the sample of firms which indicated what their hurdle rates are, but did not state what they represent (the "other" category), the WACC equivalent sample (those who marked WACC as their hurdle rates plus the WACC of the levered/unlevered cost of equity subsample), finally, the sample for which we can match with Compustat, CRSP, and Barra data bases. In the next section we analyze the determinants of the hurdle premium using this last sample. The summary statistics for all respondents in Panel A show that the mean hurdle rate is $14.8 \%$ in nominal terms (the median is $15.0 \%$ ). In this sample none of the numbers is less than $5 \%$, and the maximum hurdle rate used is $40 \%$. Furthermore, the skewness coefficient of 1.7 indicates that the distribution is fairly symmetric, and the kurtosis coefficient of 9.6 confirms that the distribution is centered around the mean and median. Adjusting for the average realized inflation of 2.2\% during the two years preceding the survey date (January 2001 to December 2003) produces an average real hurdle rate of $12.3 \%$, which is essentially same as the $12.2 \%$ real hurdle rate reported by Poterba and Summers (1995). The mean and median of the WACC equivalent sample are $14.1 \%$, and $14.0 \%$, respectively. Next, we look at those firms for which we can match Barra betas and CRSP/Compustat data. Again, the means and medians are very close to those for the full sample. Thus, sample selection does not change the characteristics of the hurdle rate distribution.

Panel B of Table IV reports the industry composition of firms in each sample. Comparing the first (full) sample, and the sample we use in our tests (the last sample), suggest that there is 
no industry related bias. Examination of Panel $\mathrm{C}$ leads to the conclusion that other than the standard deviation for the manufacturing firms (which is somewhat higher), the summary statistics across industries are similar.

\section{Modeling Hurdle Rates}

In order to test our hypothesis that firms screen projects by adding a hurdle premium to their cost of capital and to explore the determinants of the premium, we propose a model that explains hurdle rates by the weighted average cost of capital plus a linear combination of firm characteristics that are likely to be related to the value of the option to wait. We use nonlinear least squares estimation to solve simultaneously for the equity premium that firms use to compute their cost of equity and WACC, and the loadings on firm characteristics that proxy for the value of the option to wait.

$$
\text { Hurdle }=W A C C+a+\sum_{j=1}^{k} b_{j} \operatorname{Char}_{j}+\varepsilon
$$

where,

$$
\begin{aligned}
& \text { WACC }=\frac{D}{D+E} r_{D}(1-\mathrm{Tax})+\frac{E}{D+E} r_{E} \\
& r_{E}=r_{F}+\beta_{M K T} P_{M K T} \\
& r_{E}=r_{F}+\beta_{M K T} P_{M K T}+\beta_{S M B} P_{S M B}+\beta_{H M L} P_{H M L}
\end{aligned}
$$

In the CAPM specification (3a) we use the fundamental Barra beta. In the three factor specification (3b), in order to get the beta coefficients for SMB and HML we first subtract $\beta_{\text {Barra }} r_{M K T}$ from monthly returns to get a time series of residual returns in excess of what can be explained by market returns. 


$$
r_{E}-r_{F}+\beta_{\text {Barra }} r_{M K T}
$$

We then regress five years of monthly residual returns prior to the survey date on the returns of the factor-mimicking portfolios for SMB and HML.

The firm characteristics variables that we include in our model are: cash-to-assets ratio, average industry stock returns during the five years prior to the survey date, the average Rsquares of the market model in the industry that the firm belongs (again using 5 years worth of monthly observations), sales growth per employee, and Altman’s Z- score.

Due to tax related costs of holding excess cash and agency costs, we expect growth firms to have high cash-to-assets ratio. There is ample evidence that shareholders force non-growth firms to distribute their cash holdings. For example, Nohel and Tarhan (1998) show that firms with low $\mathrm{Q}$ ratios improve their operating performance by distributing cash via share repurchases. The value of the option to wait should be higher for high-growth firms, since it may enable these firms to undertake future projects that are more valuable than the positive NPV projects they have in the present period. These firms are likely to screen projects using a hurdle rate that exceeds their WACC. At the same time, due to the possibility that they may face difficulties in the future when valuable projects materialize, they are likely to maintain high financial flexibility in the current period by having a high cash-to-assets ratio. Thus, we expect cash-to-assets to have a positive sign.

Financially healthy firms are likely to have higher growth prospects. Thus, measures of financial health, such as Altman's Z-score, are expected to have a positive estimated coefficient. ${ }^{10}$ Systematic risk is also likely to be positively related to hurdle rates. Holding other

\footnotetext{
${ }^{10}$ For financially unhealthy firms, a measure of how close the firm is to bankruptcy is likely to be positively correlated with hurdle rates. As probability of bankruptcy increases, provided that the firm has time to wait before chapter 11 or liquidation, the higher is the value of option to wait. This represents a lottery type of situation. Rather than accepting a project which has a positive NPV where the NPV is not
} 
firm characteristics constant, fundamental Barra beta will be positively correlated with hurdle rates since it would mean a higher WACC.

Since stock prices reflect anticipated future growth, industries with high past returns are likely to have high growth prospects in the future. The average expected NPV of future projects, in turn, is likely to be positively correlated with the growth prospects of the industry. For this reason, firms that belong to industries with high average returns are likely to have high hurdle premia.

Dispersion of the distribution of future NPVs is driven by the riskiness of the industry. The firm has to decide whether it is optimal to accept a current positive NPV project or wait for a possibly better one by using a hurdle rate with two components - WACC and the hurdle premium. Holding the point estimate of beta constant, the lower is the R-squares of the market model, the wider is the dispersion, thus, the higher is the value of the option for waiting. ${ }^{11}$

Finally, managerial and other human capital constraints will influence hurdle rates in the positive direction. High-growth firms are likely to have high opportunity costs of not waiting for possible better projects in the future due to limited managerial talent. These firms are likely to place a high value on the option to wait. Since in corporate finance the term "growth" concerns the sales variable, we use a categorical variable sales growth per employee to capture human capital constraints.

\section{Empirical Findings}

high enough to materially change the firm's situation, it would be reasonable for the firm to reject the project by using a high hurdle rate in hopes of encountering a project with a high enough NPV that would make a difference in the firm's value.

${ }^{11}$ There is also the possibility that unsystematic risk may also play a role (Goyal and Santa-Clara (2003)). First, managers may feel that shareholders are not fully diversified and price this risk in their hurdle rates. Second, lower R-squares involve a wider confidence around the point estimate for beta and, to be on the safe, side managers may use higher rather than lower hurdle rates when the R-squares is low. 
Table $\mathrm{V}$ displays the results from various models that we use to determine the relative importance of WACC, and variables related to the option to wait, in explaining the crosssectional variation in hurdle rates. In Columns 1 and 2 we show the results from estimating (1), (2), for the single factor CAPM (equation 3a), and the Fama-French three factor model (3b), respectively. The $3.8 \%$ equity premium estimate obtained from the single factor CAPM is identical to Graham and Harvey (2005), who in a survey they conduct at approximately the same date as our survey, find the average expected equity premium to be $3.8 \%$ (median $3.6 \%$ ).

The cash-to-assets is positively correlated with hurdle rates (at $1 \%$ level of significance). Simutin (2010) finds that firms with high cash balances generate higher future stock returns. Based on this finding, he argues that excess cash holdings proxy for high growth opportunities. Since high growth opportunities imply a high valuation for the option to wait, the positive correlation between cash and hurdle rate is as expected. ${ }^{12}$

The dispersion of the distribution of future NPVs is driven by the riskiness of the industry, and since low R-squares obtained from estimating the market model of individual firms in the same industry imply a wider dispersion, the expected correlation between average industry R-squares and hurdle rates is negative. This expectation is confirmed by the highly significant negative coefficient for the R-squares variable. The positive estimate (significant at the $1 \%$ level) for the sales growth per employee variable is also as expected. We use this variable as a proxy for managerial and organizational constraints. Growth firms are more likely to find this constraint to be binding. As a result, they would put a high value for the option to wait. The

\footnotetext{
${ }^{12}$ Opler, Pinkowitz, Stulz, and Williamson (1999) analyze the tradeoff between the benefits and costs of cash holdings. While cash holdings create value by providing financial flexibility to take advantage of future profitable projects, cash holdings also involve tax related costs and agency costs (e.g., by enabling managers to engage in empire building types of activities). In fact, Pinkowitz, Stulz, and Williamson (2006) find that in countries with weak investor protection, cash is discounted at a higher rate. However, in countries with intense shareholder activism (such as the U.S.), benefits of cash exceed its potential costs (especially in the case of growth firms).
} 
positive and highly significant estimate for the variable in question is consistent with this interpretation.

Thus, the three variables discussed above each have the expected sign and are statistically significant. However, even though the other two variables - average industry return, and the financial health of a firm as measured by Altman's Z-score - are, as expected, positively correlated with the value of the option to wait, the financial health variable is not statistically significant when CAPM is used (it is significant at the $5 \%$ level when the three-factor model is used). The model estimated in Column 1, explains $45 \%$ of the cross-sectional variation in hurdle rates. Furthermore, Panel A of Figure 4 shows the relation between the predicted values of hurdle rates (horizontal axis), and the actual hurdle rates (vertical axis). The 45 degree line in the figure is superimposed. However, when we run a regression of predicted values on actual hurdle rates we obtain a slope that is not statistically different from one (estimated slope coefficient is 0.87 with a standard error of 0.15 ), and the estimate for the intercept is 0.025 (with a p-value of 0.27).

In Table V, Column (2) displays the results from estimating (1), and (2) using the threefactor model (3b). An interesting result is that the estimated loading on the HML factor is negative. The literature finds that value stocks earn higher returns than growth stocks. The negative estimated coefficient for the HML factor indicates that growth firms use higher hurdle rates than value firms. Thus, while value firms earn higher returns, growth firms expect to earn more on their future projects and use higher hurdle rates. At the same time, the estimated equity premium becomes smaller in this specification. However, the 3.8\% equity premium estimate of Column 1 is still within one standard deviation of the estimate for the equity premium in Column 2. The results also show that the SMB loading is unrelated to hurdle rates. Given that small 
firms are more likely to suffer from financial constraints, this suggests that capital rationing cannot explain the high hurdle rates. Another finding is that estimated coefficients for variables that proxy for the value of option to wait are robust with respect to whether the single-factor CAPM or the three-factor model is used. The three factor model has slightly higher explanatory power than CAPM (0.49 vs. 0.45). Finally, we find that in our models the intercept coefficient is not statistically different from zero. This suggests that we are not missing any systematic adjustments managers may be making to hurdle rates, such as using a higher hurdle rate to account for possible optimism in the cash flow projections.

It is possible that the results in columns 1 and 2 may be driven by the non-linear specification and also by simultaneously solving for the implied equity premium. To see whether or not this is the case, in Columns 3 and 4, we repeat the two exercises by including the three components of WACC in linear regression models for the single and three-factor models without simultaneously inferring the equity premium. The results displayed are remarkably similar to those in columns 1 and 2 in terms of magnitudes, statistical significance, and explanatory power. The similarity of the options related coefficients across the four columns indicate that the results are robust not just with respect to the non-linear and linear specifications, but also with respect to CAPM vs. the three-factor model. Taken together, this suggests that the variables we use to proxy for the option value to wait are orthogonal to the cost of capital component of hurdle rates.

This observation is confirmed by Panels B and C of Figure 4 which break up the two components of hurdle rates. As in Panel A, both Panels B and C have the 45 degree line superimposed. In Panel B the horizontal axis is the predicted WACC, while the hurdle rate minus the predicted hurdle premium (i.e., cost of capital plus the error term) is plotted on the 
vertical axis. The estimated slope coefficient is not statistically different from one (0.93, with standard errors of 0.30$)$, and the intercept is not different from zero (0.011 with a $p$-value of 0.63). Panel $\mathrm{C}$ examines the hurdle rate premium by plotting the predicted hurdle premium (horizontal axis) against hurdle rate minus implied WACC using 3.8\% as the equity premium (vertical axis). As in Panels A and B, the slope and intercept terms in Panel C are not different from one and zero, respectively.

In Table VI we pursue the relative importance of cost of capital and the option value to wait components of hurdle rates in explaining both the levels of and the cross-sectional variation in hurdle rates. In (5) and (6) we examine the cost of capital component using CAPM and the three-factor model, respectively. Judging by the R-squares of 0.11 and 0.17 , we conclude that cost of capital is an important component. In fact using beta alone (Model 7) results in an R-square of only 0.03 . The failure of (5) to satisfactorily explain hurdle rates can also be seen in Panel A of Figure 5: only one of the observations is below the 45 degree line. Apparently, this situation cannot be attributed to the inferred equity premium of 3.8\% since using the historical risk premium of 6.6\% (Panel B) does not produce a material improvement. ${ }^{13}$

Two additional comments are in order: One, the intercept estimates in (5) and (6) indicate that $6.3 \%$ to $7.7 \%$ of the average levels of hurdle rates cannot be explained by WACC. Two, while the cost of capital component belongs in the specification of hurdle rates, it is less important in explaining the variation in hurdle rates than the option to wait component. The linear model in (9) has an R-square of 0.37 suggesting that the premium component has approximately three times the explanatory power of the cost of capital component. However, in spite of this, based on the estimated intercept of 0.079 , this component alone is not sufficient in

13 Welch (2000) reports that academic financial economists forecast an arithmetic average equity premium over a 10-year horizon of $7 \%$. 
explaining the hurdle rates either. The implication that emerges from Table VI is that the specification of hurdle rates needs to include variables that capture both components. Combining the findings of Tables V and VI reveals that our non-linear models which simultaneously infer the equity premium (Models 1 and 2 of Table V) are superior to the two linear models that incorporate both components (Models 3 and 4 in Table V). Our models have the highest explanatory power ( 0.45 vs. 0.41 when CAPM is used and 0.49 vs. 0.48 when the three-factor model is used). At the same time, our two models have intercept estimates that are undistinguishable from zero. In sum, our models succeed in explaining both the average levels of hurdle rates and also the cross-sectional variation of hurdle rates.

\section{Conclusion}

We examine the cross-sectional variation in hurdle rates that firms use in their capital budgeting decisions. We find that managers systematically add a hurdle premium to their CAPM based cost of capital. The size of this premium is substantial; it makes up about one half of the average hurdle rate used in practice. Following McDonald and Siegel (1986) we argue that the option to defer investments can explain the hurdle premium. This option to wait is most valuable to firms with growth opportunities facing organizational capital constraints that limit the rate of growth.

We develop a model of hurdle rates where the CAPM beta enters nonlinearly through the weighted average cost of capital (WACC) and variables that proxy for the option to wait that enter linearly. The coefficient estimates corresponding to the variables that proxy for the value of the option to wait for better future investment opportunities have the right signs and are statistically significant. We find that firms with higher hurdle rates keep higher cash balances, 
which is consistent with maintaining financial flexibility to undertake future valuable projects when they materialize. Such firms tend to be growth firms loading negatively on the Fama and French (1993) HML factor, which is also consistent with our hypothesis that the option to wait is more valuable to growth firms.

The model explains the level of hurdle rates and $45 \%$ of is cross-sectional variation across firms. The implied equity premium of $3.8 \%$ that we infer from the model is identical to the average equity premium that Graham and Harvey (2005) report in their survey of CFOs. The specification of our model is robust to whether we use CAPM or the Fama-French three-factor model. Since small firms are more likely to suffer from capital rationing, the insignificant factor loading for the Fama and French (1993) SMB factor suggests that the high hurdle rates are not driven by capital market constraints. Furthermore, the zero intercept of the model suggests that managers do not use higher hurdle rates to compensate for optimistic cash flow projections.

While we find both the cost of capital and the hurdle premium components to be important, cost of capital can only explain $10 \%$ of the variation in hurdle rates across firms, whereas proxies for the option to wait explain 35\%. Further, the variation of the hurdle premium across firms is three times the variation in cost of capital.

Our analysis reconciles two seemingly contradictory findings in the literature. Since the hurdle premium (the difference between the hurdle rate used by a firm and its CAPM based cost of capital) varies substantially more than the cost of capital across firms, it masks the relation between the hurdle rate and the CAPM beta. This may explain why Poterba and Summers (1995) do not find CAPM betas to be significant in explaining hurdle rates. We also find that the CAPM based cost of capital is an important determinant of the hurdle rate that a firm uses. This is consistent with Graham and Harvey (2001) who report that most managers use the CAPM. 
We hope that our findings - that the hurdle premium is about the same as the cost of capital and varies much more across firms - will stimulate further research that will help understand how firms arrive at what hurdle premium to use. 


\section{Appendix}

Converting Levered/Unlevered Cost of Equity Hurdle Rates into WACC Equivalents

In $13.7 \%$ of the cases where survey participants indicate that they use either levered or unlevered cost of equity as their hurdle rate, we transform these cost of equity figures to their weighted average cost of capital (WACC) equivalents. If they indicate that the hurdle rate represents their cost of levered equity, we use this rate as the cost of equity and average it with their after-tax cost of debt and market value weights to compute their WACC. If they indicate that the hurdle rate represents their cost of unlevered equity, we check if these firms have any debt. Obviously, for the four firms that do not have any debt, unlevered cost of equity and WACC are identical. For firms with debt in their balance sheets, we lever up the reported cost of unlevered equity to obtain their cost of levered equity, and then compute WACC.

To compute WACC we use Compustat data to infer the market value-based weights for cost of debt and cost of equity. To compute the weight of debt, we divide total debt (Compustat items DLTT + DLC) by total debt plus market value of common and book value of preferred equity (CSHO $\times$ PRCC_F + PSTK). For the weight of equity we use (1 - weight of debt).

The mean life of a typical project for firms in our survey sample is 6.8 years. For this reason, we use the 10 -year Treasury bond rate, which was $4.3 \%$ at the time of our survey, as a proxy for the risk-free rate. ${ }^{14}$ For the before-tax cost of debt we use the survey participants' answers to our question regarding what the interest rate on their senior debt is. ${ }^{15}$ The survey

\footnotetext{
${ }^{14}$ This choice seems to be justified for other reasons as well: In their survey of 27 highly regarded corporations, Bruner, Eades, Harris, and Higgins (1998) find that more than $70 \%$ use a 10 -year or longerterm Treasury rate as the proxy for the risk-free rate. They report that only $4 \%$ of the firms in their survey use the 90-day T-bill rate.

${ }^{15}$ We do not know whether their answers refer to the coupon rate or the yield to maturity of their senior bonds. Thus, for firms that have not issued debt recently, it is possible that their answers do not reflect the marginal cost of debt if they report coupon rates. However, given the secular decline of interest rates
} 
provides data on the before-tax cost of debt for 88 firms. Using Compustat data, we check whether firms that left the interest rate question blank had any debt. Out of the 39 nonresponding firms we can match Compustat data for 28, and 16 of these firms turn out to have no debt. The remaining 12 firms with debt left the interest rate question blank. ${ }^{16}$ For these firms we use their Altman's Z-score and the default spreads at the time of the survey to assign interest rates. If a firm's Z-score is greater than 3, a score that indicates a very low probability of default (8 firms), we assign the 10-year Treasury bond rate in effect at the time of the survey plus 1 percent (5.3\%). For the two firms with Z-scores of less than 1.81 (financially unhealthy firms), we assign the 10-year Treasury rate plus 4 percent (8.3\%). Firms that have Z-scores in the interval between 1.81 and 3 (2 firms) are assigned a before-tax cost of debt of 6.3. Finally, for firms that report a rate below the 10-year Treasury rate (4.3\% at the time of the survey) we add a spread of $0.5 \%$ to the Treasury rate. Therefore, all our WACC calculations assume cost of debt of at least $4.8 \%$.

We calculate a firm's tax rate by dividing total income taxes (Compustat item TXT) by income before taxes PI). When item TXT or PI is negative (tax credits and negative profits, respectively), we set the tax rate to zero. Additionally, we cap the tax rate at 34 percent. $^{17}$

that started in the late 1990s and continued during the early 2000s, this should work against finding a hurdle rate premium.

${ }^{16}$ Out of these 12 firms, 2 have less than 1\% debt (as a fraction of market value of assets) and another 6 less than $5 \%$.

${ }^{17}$ The tax rate we obtain in this manner reflects a firm's average and not marginal tax rate. However, we were unable to obtain a sufficient number of observations on marginal tax rates. 


\section{References}

Antill, Nick, and Robert Arnott, 2004, Creating value in the oil industry, Journal of Applied Corporate Finance 16(1), 18-31.

Bierman, Harold J., 1993, Capital budgeting in 1992: A survey, Financial Management 22(3), 24.

Brigham, Eugene F., 1975, Hurdle rates for screening capital expenditure proposals, Financial Management 4, 17-26.

Bruner, Robert F., Eades, Kenneth M., Harris, Robert S., and Robert C. Higgins, 1998, Best practices in estimating the cost of capital: survey and synthesis, Financial Practice and Education 8, 13-28.

Cleary, Sean, 1999, The relationship between firm investment and financial status, Journal of Finance 54(2), 673-692.

Fama, Eugene F., and Kenneth R. French, 1993, Common risk factors in the returns on stocks and bonds, Journal of Financial Economics 33 (1), 3-56.

Fremgen, J. M., 1973, Capital budgeting practices: A survey, Management Accounting 54(11), 19-25.

Gillham, Bill, 2000, Developing a questionnaire, Continuum, New York, NY.

Gitman, Lawrence J., and John R. Forrester Jr., 1977, A survey of capital budgeting techniques used by major U.S. firms, Financial Management 6, 66-71.

Gitman, Lawrence J., and Vincent A. Mercurio, 1982, Cost of capital techniques used by major U.S. firms: Survey and analysis of Fortune’s 1000, Financial Management 11, 21-29.

Gitman, Lawrence J., and Pieter A. Vandenberg, 2000, Cost of capital techniques used by major U.S. firms: 1997 vs. 1980, Financial Practice and Education 10(2), 53-68.

Goyal, Amit K., and Pedro Santa-Clara, 2003, Idiosyncratic risk matters! Journal of Finance 58(3), 975-1007.

Graham, John R., and Campbell R. Harvey, 2001, The theory and practice of corporate finance: evidence from the field, Journal of Financial Economics 60, 187-243.

Graham, John R., and Campbell R. Harvey, 2005, The long-run equity risk premium, Finance Research Letters 2, 185-194.

Ibbotson, 2004. Yearbook, Ibbotson Associates, Chicago, IL. 
Istvan, Donald F., 1961, The economic evaluation of capital expenditures, Journal of Business 36, 45-51.

Jagannathan, Ravi, and Iwan Meier (2002). Do we need CAPM for capital budgeting? Financial Management 31(4), 55-77.

Kim, Suk H., Trevor Crick, and Edward J. Farragher, Foreign capital budgeting practices used by the U.S. and Non-U.S. multinational companies, The Engineering Economist 25(3), 207-215.

Klammer, Thomas P., 1972, Empirical evidence of the adoption of sophisticated capital budgeting techniques, Journal of Business 45(3), 387-397.

Klammer, Thomas P., and Michael C. Walker, 1984, The continuing increase in the use of sophisticated capital budgeting techniques, California Management Review 27(1), 137-148.

Lintner, J., 1965, The valuation of risk assets and the selection of risky investments in stock portfolios and capital budgets, Review of Economics and Statistics 47, 13-37.

Mao, James C.T., 1970, Survey of capital budgeting: Theory and practice, Journal of Finance 25(2), 349-360.

McDonald, Robert, 1998. Real options and rules of thumb in capital budgeting. In: Brennan, M.J., Trigeorgis, L. (Eds.), Innovation, Infrastructure, and Strategic Options. Oxford University Press, London.

McDonald, Robert, and Daniel Siegel, 1986, The value of waiting to invest, Quarterly Journal of Economics 101(4), 707-728.

Moore, James S., and Alan K. Reichert, 1983, An analysis of the financial management techniques currently employed by large US corporations, Journal of Business, Finance, and Accounting 10, 623-645.

Morgan, David L., 1988. Focus groups as qualitative research, Sage Publications, Newbury Park, CA.

Nohel, Tom, and Vefa Tarhan, 1998, Share repurchases and firm performance: new evidence on the agency costs of free cash flow, Journal of Financial Economics 49(2), 187-222.

Opler, Tim, Pinkowitz, Lee, Stulz, René, and Rohan Williamson, 1999, The determinants and implications of corporate cash holdings, Journal of Financial Economics 52, 3-46.

Petry, Glenn H., 1975, Effective use of capital budgeting tools, Business Horizons (October), 5765.

Petty, William J., Scott, David F., and Monroe M. Bird, 1975, The capital expenditure decisionmaking process of large corporations, The Engineering Economist 20(3), 159-172. 
Petty, William J., and Oswald D. Bowlin, The financial manager and quantitative decision models, Financial Management 5(4), 32-41é

Pinkowitz, Lee, René Stulz, and Rohan Williamson, 2006, Does the contribution of corporate cash holdings and dividends to firm value depend on governance? A cross-country analysis, Journal of Finance 61(6), 2725-2751.

Poterba, James M., and Lawrence H. Summers., 1995, A CEO survey of U.S. companies' time horizon and hurdle rates, Sloan Management Review (Fall), 43-53.

Schall, Lawrence D., Sundem,Gary L., and William R. Geijsbeek Jr., 1978, Survey and analysis of capital budgeting methods, Journal of Finance 38(1), 281-287.

Sharpe, William F., 1964, Capital asset prices: A theory of market equilibrium under conditions of risk, Journal of Finance 19, 425-442.

Simutin, Mikhail, 2010, Excess cash and stock returns, Financial Management 39(3), 11971222.

Singer, Eleanor, and Stanley Presser, 1989, Survey research methods: A reader, University of Chicago Press, Chicago, IL.

Smith, Clifford, David Ikenberry, Arun Nayar, Jon Anda, and Henry McVey, 2005, Morgan Stanley roundtable on capital structure and payout policy, Journal of Applied Corporate Finance 17(1), 36-53.

Trahan, Emery A., and Lawrence J. Gitman, 1995, Bridging the theory-practice gap in corporate finance: A survey of chief financial officers, Quarterly Review of Economics and Finance 35(1), 73-87.

Welch, Ivo, 2000, Views of financial economists on the equity premium and on professional controversies, Journal of Business 73 (4), 501-537.

Womack, Kent L., and Ying Zhang, 2005, Core Finance Course Trends in the Top MBA Programs in 2005, working paper, Dartmouth College. 
Table I: Comparison of survey samples.

Panel A shows the industry breakdown using 2-digit SIC codes. “-” indicates that these sectors were excluded from the survey/sample or not listed as a category in the questionnaire. Panel B shows summary statistics on hurdle rate and the percentage of survey respondents that use CAPM and WACC.

Panel A

\begin{tabular}{lcccccc}
\hline Industry & $\begin{array}{c}\text { SIC } \\
\text { Code }\end{array}$ & $\begin{array}{c}\text { Poterba and } \\
\text { Summers (1995) }\end{array}$ & $\begin{array}{c}\text { Bruner, Eades, } \\
\text { Harris, and } \\
\text { Higgins (1998) }\end{array}$ & $\begin{array}{c}\text { Graham and } \\
\text { Harvey (2001) }\end{array}$ & $\begin{array}{c}\text { Compustat } \\
(2003)\end{array}$ & $\begin{array}{c}\text { Jagannathan, } \\
\text { Meier, and } \\
\text { Tarhan (2010) }\end{array}$ \\
\hline Agriculture, forestry, fishing & $01-09$ & 0.0 & 3.7 & - & 0.6 & 0.0 \\
Mining, construction & $10-17$ & 4.4 & 0.0 & 4.0 & 10.5 & 10.7 \\
Manufacturing & $20-39$ & 60.6 & 77.8 & $51.3^{(\mathrm{a})}$ & 64.5 & 66.0 \\
Transportation, communication & $40-49$ & 12.5 & 11.1 & $18.2^{(\mathrm{b})}$ & $10.1^{(\mathrm{c})}$ & $10.7^{(\mathrm{c})}$ \\
Wholesale and retail trade & $50-59$ & 6.9 & 3.7 & 11.1 & 13.7 & 11.6 \\
Finance, insurance, and real estate & $60-67$ & 6.9 & - & 15.4 & - & - \\
Services & $70-89$ & 5.6 & 3.7 & - & $392^{(\mathrm{g})}$ & 5,108 \\
\hline Total obs. & & $228^{(\mathrm{e})}$ & $27^{(\mathrm{f})}$ & & $1.0^{(\mathrm{d})}$ & 127 \\
\hline
\end{tabular}

\section{Panel B}

\begin{tabular}{lccc}
\hline Hurdle Rate & & & \\
\hline Mean & $\begin{array}{r}12.2 \%(\text { real })^{(\mathrm{h})} \\
=17.8 \% \text { nom }\end{array}$ & & $14.8 \%($ nominal) \\
& & & 1 \\
Median & $10.0 \% \%^{(\mathrm{i})}$ & & $5.0 \%$ \\
Standard deviation & $\sim 5.6 \%{ }^{(\mathrm{k})}$ & & $5.0 \%$ \\
\hline Use CAPM & & $81 \%^{(\mathrm{l})}$ & $74 \%$ \\
Use WACC & $85 \%^{(\mathrm{m})}$ & & $71.8 \%$ \\
\hline
\end{tabular}


Notes to Table I:

(a) Combines the survey categories "manufacturing” and "high-tech”; excludes "energy” (see footnote c below) which is reported in the survey category "transportation/energy".

(b) Including "energy"; SIC codes 46, 49 (5540 and 5541).

(c) Excluding radio/TV and utilities providing gas, electricity, and water supply (SIC codes 4830, 4941).

(d) Only SIC code 70 (hotels, other lodging places).

(e) 160 respondents identified their firms. The questionnaire was sent to each CEO in the 1990 Fortune 1,000 list.

(f) Firms that were selected by their peers for best financial management practices according to Business International Corporation (1992), “Creating World-Class Financial Management: Strategies of 50 Leading Companies,” Research Report 1-110, New York, NY, 7-8. From the 50 companies, 18 with headquarters outside the US were excluded, 5 declined to participate.

(g) Questionnaires were sent by mail to each CFO in the 1998 Fortune 500 list and faxed out to 4,400 Financial Executives International (FEI) member firms. The raw data and a detailed description of the dataset are available on Campbell R. Harvey's website.

(h) $66.2 \%$ of the respondents report nominal rates and the authors convert these to real rates using a long-term expected inflation rate of $5 \%$.

(i) Page 46: $1 / 3$ of all firms use $<10 \%$ and the most common rate, used by $1 / 5$ of the firms, is $10 \%$.

(k) This is an approximation based on the midpoints of the categories and the frequencies shown in Figure 2 (page 46).

(l) An additional 4\% use sometimes WACC, only 4\% answered no (2 firms did not answer this question). 89\% use some form of cost of capital as their discount rate (an additional 7\% sometimes).

(m) An additional 4\% use a modified version of CAPM. 


\section{Table II: Firm characteristics of surveyed firms.}

The mean and median firm characteristics are tabulated for the 93 responding firms for which we can match with Compustat data in 2003 and for the 3,832 non-responding firms in Compustat. We exclude utilities, radio/TV broadcasting, cable, and other pay TV services (4840-4999), finance and insurance companies (SIC codes 6000-6499, 6700-6799), and health/education/social services, and museums $(7200+)$. Book value of assets is Compustat item AT. Market value of assets is defined as book value of liabilities (LT) plus market value of assets, which is the sum of preferred stock (PSTK) and market value of common equity (PRCC_F $\times$ CSHO). Current ratio is current assets divided by current liabilities (ACT / LCT), total debt is the sum of debt in current liabilities plus long-term debt (DLC + DLTT), and return on book equity is the ratio between net income and book equity (NI / CEQ). For the characteristics that are expressed as fractions of book assets, we trim the top and bottom $0.5 \%$ of all Compustat firms, and then report the characteristics for responding survey firms and non-responding Compustat firms. The last two columns show the $p$-values for the difference in mean $t$-test and Fishers's exact test for differences in medians under the null hypothesis of zero mean and median, respectively.

\begin{tabular}{|c|c|c|c|c|c|c|}
\hline & \multicolumn{2}{|c|}{$\begin{array}{l}\text { Survey } \\
N=93\end{array}$} & \multicolumn{2}{|c|}{$\begin{array}{c}\text { Computstat } \\
N=3,832\end{array}$} & \multicolumn{2}{|c|}{$\begin{array}{c}\text { Difference tests } \\
p \text {-values }\end{array}$} \\
\hline & Mean & Median & Mean & Median & Mean & Median \\
\hline Book assets & 4,293 & 524 & 2,556 & 158 & 0.23 & 0.00 \\
\hline Market assets & 8,821 & 680 & 4,168 & 279 & 0.02 & 0.00 \\
\hline Sales & 4,142 & 373 & 2,392 & 144 & 0.15 & 0.01 \\
\hline Market/book assets & 2.37 & 1.69 & 3.09 & 1.60 & 0.21 & 0.46 \\
\hline Cash/book assets & 0.15 & 0.07 & 0.20 & 0.11 & 0.05 & 0.09 \\
\hline Sales/book assets & 0.66 & 0.47 & 0.70 & 0.51 & 0.27 & 0.75 \\
\hline Current ratio & 2.53 & 1.80 & 2.87 & 1.97 & 0.27 & 0.25 \\
\hline Total debt/book assets & 0.29 & 0.24 & 0.29 & 0.19 & 0.99 & 0.40 \\
\hline Capital expenditures/book assets & 0.06 & 0.04 & 0.04 & 0.03 & 0.00 & 0.09 \\
\hline Operating income/book assets & 0.05 & 0.07 & 0.02 & 0.05 & 0.03 & 0.01 \\
\hline Return on book equity & -0.01 & 0.05 & 0.07 & 0.07 & 0.38 & 0.40 \\
\hline
\end{tabular}




\section{Table III: Hurdle rates and financial characteristics.}

The table shows coefficients and standard errors (in brackets below) for bivariate regressions. The dependent variable in all regressions is self-reported hurdle rate. All explanatory variables are defined as in Figure 2 above, with the exception of the dividend payout ratio that is expressed in \% to make the coefficients comparable to Poterba and Sommers (1995). *** indicates significance at the $1 \%$ level, ** at the $5 \%$ level, and * at the $10 \%$ level. Standard errors are below in brackets.

\begin{tabular}{|c|c|c|c|c|}
\hline \multirow[t]{2}{*}{ Characteristics } & \multicolumn{2}{|c|}{ Poterba and Summers (1995) } & \multicolumn{2}{|c|}{$\begin{array}{c}\text { Jagannathan, Meier, and } \\
\text { Tarhan (2010) }\end{array}$} \\
\hline & All firms & Manufacturing & All firms & Manufacturing \\
\hline $\mathrm{P} / \mathrm{E}$ ratio & $\begin{array}{r}-0.008 \\
(0.031)\end{array}$ & $\begin{array}{r}-0.018 \\
(0.036)\end{array}$ & $\begin{array}{r}-0.019 \\
(0.020)\end{array}$ & $\begin{array}{l}-0.018 \\
(0.029)\end{array}$ \\
\hline Dividend payout ratio (in \%) & $\begin{array}{r}-0.002 \\
(0.002)\end{array}$ & $\begin{array}{r}-0.002 \\
(0.002)\end{array}$ & $\begin{array}{r}-0.026 \\
(0.020)\end{array}$ & $\begin{array}{r}-0.027 \\
(0.026)\end{array}$ \\
\hline Current ratio & $\begin{array}{l}1.889 * * * \\
(0.633)\end{array}$ & $\begin{array}{l}1.891^{* * *} \\
(0.746)\end{array}$ & $\begin{array}{l}0.791^{* * *} \\
(0.196)\end{array}$ & $\begin{array}{l}0.776^{* * *} \\
(0.240)\end{array}$ \\
\hline \% change in EPS (past 10 years) & $\begin{array}{c}0.062 \\
(0.051)\end{array}$ & $\begin{array}{c}0.072 \\
(0.055)\end{array}$ & $\begin{array}{l}-0.035 \\
(0.219)\end{array}$ & $\begin{array}{l}-0.221 \\
(0.321)\end{array}$ \\
\hline Total equity return (past 10 years) & $\begin{array}{r}-0.052 \\
(0.052)\end{array}$ & $\begin{array}{r}-0.039 \\
(0.057)\end{array}$ & $\begin{array}{r}-0.168 \\
(0.433)\end{array}$ & $\begin{array}{r}-0.663 \\
(0.745)\end{array}$ \\
\hline Historical beta & $\begin{array}{r}-0.102 \\
(1.411)\end{array}$ & $\begin{array}{r}-0.067 \\
(2.038)\end{array}$ & $\begin{array}{c}0.754 \\
(0.834)\end{array}$ & $\begin{array}{c}2.048 \\
(1.375)\end{array}$ \\
\hline Fundamental beta & & & $\begin{array}{l}1.950 \\
(1.249)\end{array}$ & $\begin{array}{c}3.127 * \\
(1.884)\end{array}$ \\
\hline Equity market-to-book & $\begin{array}{r}-0.187 \\
(0.170)\end{array}$ & $\begin{array}{r}-0.287 \\
(0.307)\end{array}$ & $\begin{array}{c}0.127 \\
(0.168)\end{array}$ & $\begin{array}{c}0.046 \\
(0.217)\end{array}$ \\
\hline Tobin's q ratio & $\begin{array}{r}-0.043 \\
(0.622)\end{array}$ & $\begin{array}{r}-0.336 \\
(0.777)\end{array}$ & $\begin{array}{l}1.229 \\
(0.715)\end{array}$ & $\begin{array}{c}1.384 \\
(1.054)\end{array}$ \\
\hline Stock turnover rate & $\begin{array}{c}0.003 \\
(0.007)\end{array}$ & $\begin{array}{c}0.008 \\
(0.008)\end{array}$ & $\begin{array}{c}0.459 \\
(0.381)\end{array}$ & $\begin{array}{l}1.005^{*} \\
(0.560)\end{array}$ \\
\hline
\end{tabular}


Table IV: Statistics on hurdle rates and industry affiliation.

Panel A shows summary statistics of self-reported hurdle rates for three samples (in percent). The hurdle rates represent the nominal rate that the company has used for a typical project during the previous two years. In the column "WACC equivalent sample" we drop firms do not use WACC or cost of levered/unlevered equity (category "other”). We convert self-reported hurdle rates that represent the cost of levered or unlevered equity are to their weighted average cost of capital (WACC) equivalents. This conversion procedure is explained in Section III.C. For two out of the 17 firms that use either cost of equity or unlevered cost of equity we cannot match the debt-equity ratio from Compustat to calculate the WACC equivalent. Therefore, we report the 101 WACC equivalent hurdle rates. The last column shows the sample statistics for WACC equivalent hurdle rates for which we can match beta from Barra and information from CRSP/Compustat. Panel B tabulates the fractions of firms in each industry.

Panel A

\begin{tabular}{lcccc}
\hline Hurdle rate & $\begin{array}{c}\text { All } \\
\text { respondents }\end{array}$ & $\begin{array}{c}\text { Category } \\
\text { "other” }\end{array}$ & $\begin{array}{c}\text { WACC } \\
\text { equivalent } \\
\text { sample }\end{array}$ & $\begin{array}{c}\text { Sample matched } \\
\text { with Barra and } \\
\text { CRSP/Compustat }\end{array}$ \\
\hline Mean & 14.8 & 17.6 & 14.1 & 14.5 \\
Median & 15.0 & 15.0 & 14.0 & 14.9 \\
Minimum & 5.0 & 9.0 & 5.0 & 7.0 \\
Maximum & 40.0 & 40.0 & 30.0 & 30.0 \\
Std. dev. & 5.3 & 6.4 & 4.9 & 4.3 \\
25th percentile & 12.0 & 12.0 & 10.8 & 12.0 \\
75th percentile & 16.0 & 22.5 & 15.0 & 16.0 \\
Skewness & 1.4 & 0.7 & 1.7 & 1.0 \\
Kurtosis & 6.7 & 2.2 & 9.6 & 4.6 \\
\hline $\mathrm{N}$ & 119 & 18 & 101 & 73 \\
\hline
\end{tabular}

Panel B

\begin{tabular}{lcccc}
\hline Industry & $\begin{array}{c}\text { All } \\
\text { respondents }\end{array}$ & $\begin{array}{c}\text { Category } \\
\text { "other” }\end{array}$ & $\begin{array}{c}\text { WACC } \\
\text { equivalent } \\
\text { sample }\end{array}$ & $\begin{array}{c}\text { Sample matched } \\
\text { with Barra and } \\
\text { CRSP/Compustat }\end{array}$ \\
\hline Mining, construction & 10.7 & 28.6 & 8.3 & 8.1 \\
Manufacturing & 66.0 & 50.0 & 67.9 & 66.2 \\
Transport, communication & 10.7 & 14.3 & 10.7 & 12.2 \\
Wholesale and retail trade & 11.6 & 0.0 & 11.9 & 12.2 \\
Services & 1.0 & 7.1 & 1.2 & 1.3 \\
\hline
\end{tabular}

Panel C

\begin{tabular}{lrrrcrc}
\hline Industry & N & Mean & Median & $\begin{array}{c}\text { Standard } \\
\text { deviation }\end{array}$ & Min & Max \\
\hline Mining, construction & 6 & 13.1 & 12.5 & 3.8 & 9.0 & 20.0 \\
Manufacturing & 48 & 15.2 & 15.0 & 4.3 & 7.0 & 30.0 \\
Transport, communication & 9 & 12.4 & 12.0 & 2.2 & 9.0 & 15.0 \\
Wholesale and retail trade & 9 & 14.2 & 15.0 & 2.2 & 8.5 & 16.0 \\
Services & 1 & 14.0 & 14.0 & - & 14.0 & 14.0 \\
\hline
\end{tabular}


Table V: Model to explain hurdle rates.

The dependent variable in all models is hurdle rate (WACC equivalent). The values for the equity premium and SMB and HML show implied premia from the model estimation. Beta is the fundamental Barra beta. Debt-to-assets is total debt (Compustat items DLC + DLTT) divided by market value of assets, which is book value of total liabilities and preferred stock plus shares of common stock outstanding times price (LT + PSTK + PRCC_F $\times$ CSHO). Cash/assets is CHE to market value of assets, industry return is the average monthly return of the firms in the same 2-digit SIC industry over the past 5 years, and the industry R-square is the average R-square from the index model of firms in the same 2digit SIC industry (using 5 years of monthly returns and the S\&P 500 as the index). Sales growth/employee ([(SALE $\left.\left.{ }_{t}-\mathrm{SALE}_{t-1}\right) / \mathrm{SALE}_{t-1}\right] / \mathrm{EMP}$ is a categorical variable where firms are assigned to 1 if the value is lower than mean -2 standard deviations across all firms; the next category is from mean -2 std. dev. to mean -1.5 std. dev., for which we assign 2, etc. For values larger than mean +2 std.dev. we assign 10. Financial health (Altman's Z-score) is a categorical variable which is 1 if z-score $<1.81$ (financially unhealthy), 2 if $\mathrm{z}$-score $\geq 1.81$ and $<3$ (neutral), and 3 if $\geq 3$ (financially very healthy firms).

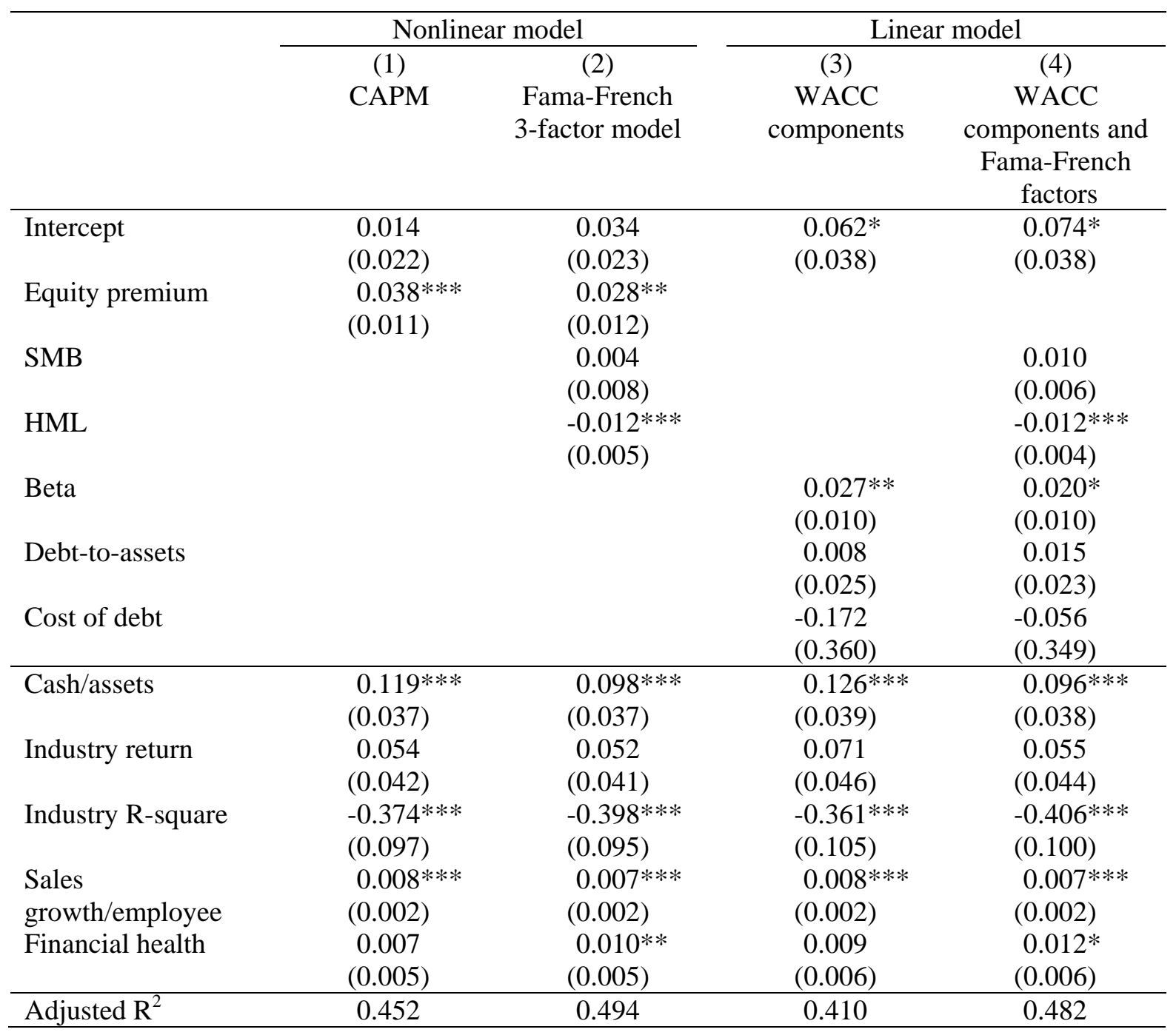


Table VI: Separating WACC and the explanatory variables for hurdle premium.

The dependent variable is hurdle rate (WACC equivalent). Variable definitions are the same as in Table V.

\begin{tabular}{|c|c|c|c|c|c|}
\hline & \multicolumn{2}{|c|}{ Nonlinear model } & & \multicolumn{2}{|c|}{ Linear model } \\
\hline & $\begin{array}{c}\text { (5) } \\
\text { CAPM }\end{array}$ & $\begin{array}{c}\text { (6) } \\
\text { Fama-French } \\
\text { 3-factor model }\end{array}$ & $\begin{array}{c}\text { (7) } \\
\text { Only beta }\end{array}$ & $\begin{array}{c}(8) \\
\text { WACC } \\
\text { components }\end{array}$ & $\begin{array}{c}(9) \\
\text { Model without } \\
\text { WACC }\end{array}$ \\
\hline Intercept & $\begin{array}{l}0.063^{* * *} \\
(0.011)\end{array}$ & $\begin{array}{l}0.077^{* * *} \\
(0.038)\end{array}$ & $\begin{array}{l}0.124^{* * * *} \\
(0.012\end{array}$ & $\begin{array}{l}0.158^{* * * *} \\
(0.024)\end{array}$ & $\begin{array}{l}0.079 * * * \\
(0.024)\end{array}$ \\
\hline Equity premium & $\begin{array}{l}0.047 * * * \\
(0.011)\end{array}$ & $\begin{array}{l}0.031^{* *} \\
(0.014)\end{array}$ & & & \\
\hline SMB & & $\begin{array}{c}0.009 \\
(0.008)\end{array}$ & & & \\
\hline HML & & $\begin{array}{l}-0.014^{* *} \\
(0.006)\end{array}$ & & & \\
\hline Beta & & & $\begin{array}{c}0.020^{*} \\
(0.011)\end{array}$ & $\begin{array}{l}0.026^{* *} \\
(0.011)\end{array}$ & \\
\hline Debt-to-assets & & & & $\begin{array}{l}-0.035 \\
(0.025)\end{array}$ & \\
\hline Cost of debt & & & & $\begin{array}{l}-0.052 \\
(0.410)\end{array}$ & \\
\hline Cash/assets & & & & & $\begin{array}{l}0.158^{* * * *} \\
(0.038)\end{array}$ \\
\hline Industry return & & & & & $\begin{array}{c}0.055 \\
(0.045)\end{array}$ \\
\hline Industry R-square & & & & & $\begin{array}{l}-0.284^{* * *} \\
(0.100)\end{array}$ \\
\hline Sales growth/employee & & & & & $\begin{array}{l}0.008^{* * * *} \\
(0.003)\end{array}$ \\
\hline Financial health & & & & & $\begin{array}{c}0.006 \\
(0.005)\end{array}$ \\
\hline Adjusted $\mathrm{R}^{2}$ & 0.114 & 0.165 & 0.030 & 0.094 & 0.371 \\
\hline
\end{tabular}




\section{Figure 1: Adoption of DCF methods, WACC, CAPM, and company-wide hurdle rates over time.}

The surveys on capital budgeting practices of U.S. firms are listed in chronological order below the horizontal time axis. The scatter plot summarizes their findings regarding the percentage of firms that: (i) Use discounted cash flow (DCF) methods, including net present value (NPV), adjusted present value (APV), internal rate of return (IRR), and the profitability index (PI); (ii) Use the weighted average cost of capital (WACC) to discount cash flows; (iii) Employ the Capital Asset Pricing Model (CAPM) to compute cost of equity; and (iv) Use a company-wide hurdle rate.

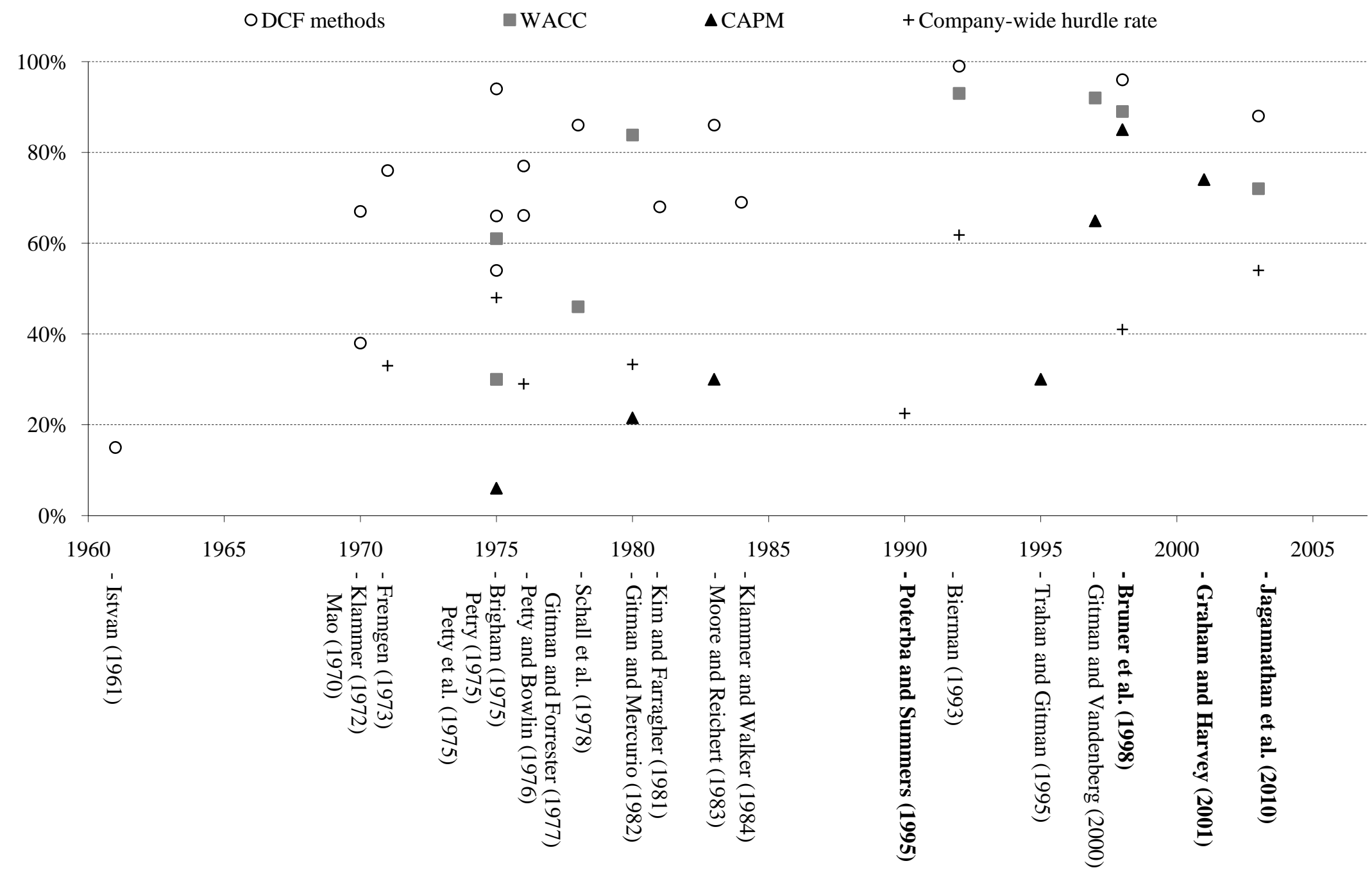




\section{Figure 2: Hurdle rates and firm characteristics.}

Kernel-weighted local polynomial regressions of hurdle rate on various firm characteristics. For the local mean smoothing we apply the Epanechnikov kernel function with a rule-of-thumb bandwidth estimator (the bandwidth is shown below the graphs). The characteristics are $\mathrm{P} / \mathrm{E}$ ratio (Compustat items PRCC_F/EPSPX), dividend ratio (DVC/IBAD), current ratio (ACT/LCT), percentage change in earnings per share $\left(\left[\mathrm{EPSPX}_{\mathrm{t}}-\mathrm{EPSPX}_{\mathrm{t}-10}\right] / \mathrm{EPSPX}_{\mathrm{t}-10}\right)$, total past equity return over 10 years

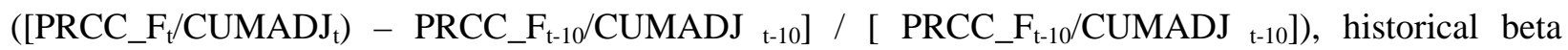
(regressing five years of monthly total stock returns on stock market returns), fundamental beta from Barra, market-to-book equity ratio ([CSHO $\times$ PRCC_F] / CEQ), Tobin's q ([AT + CSHO $\times$ PRCC_F CEQ - TXDB] / [0.9 × AT + $0.1 \times$ MKVAL]), and stock turnover rate (SHSTRD/CSHOQ). The footnote below indicates outliers that have been removed from the graphs.

A: Price-earnings ratio

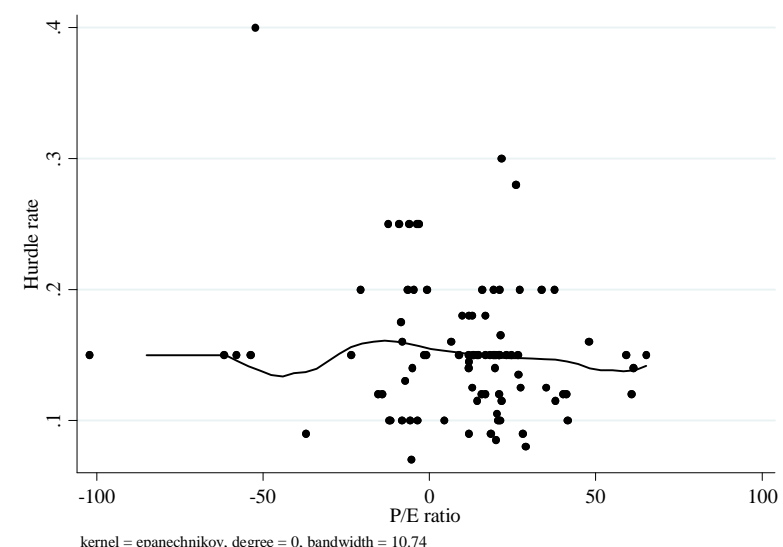

C: Current ratio

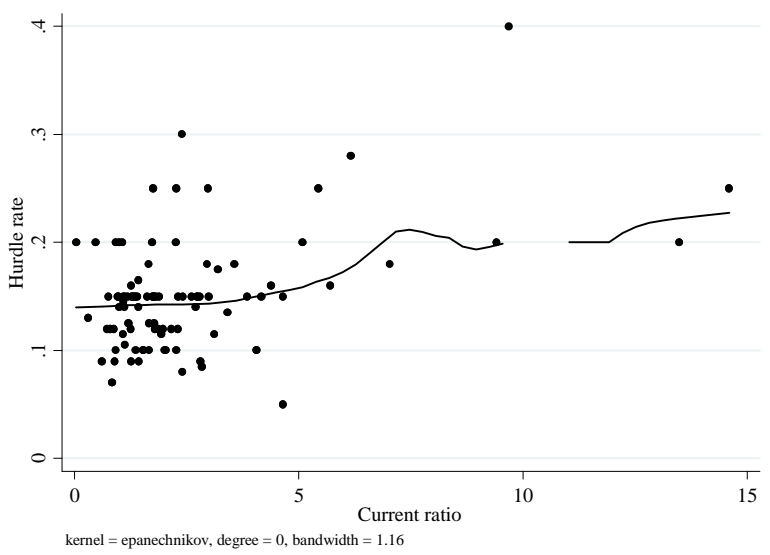

B: Dividend payout ratio

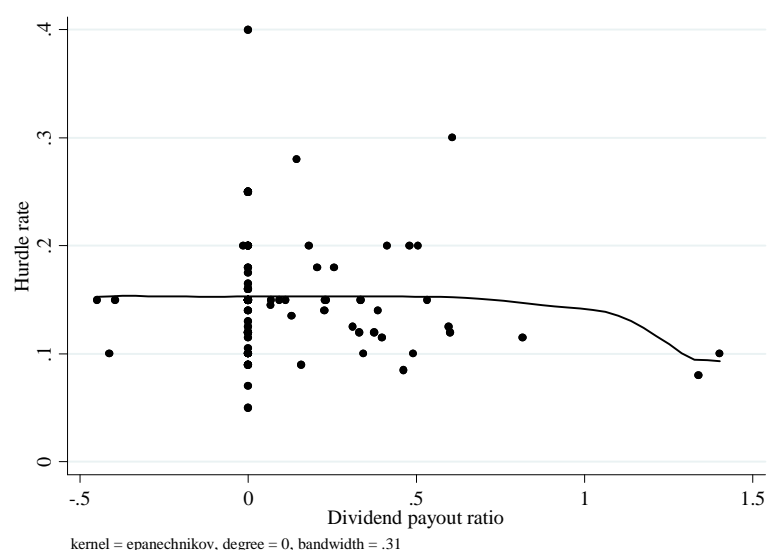

D: Percentage change in EPS

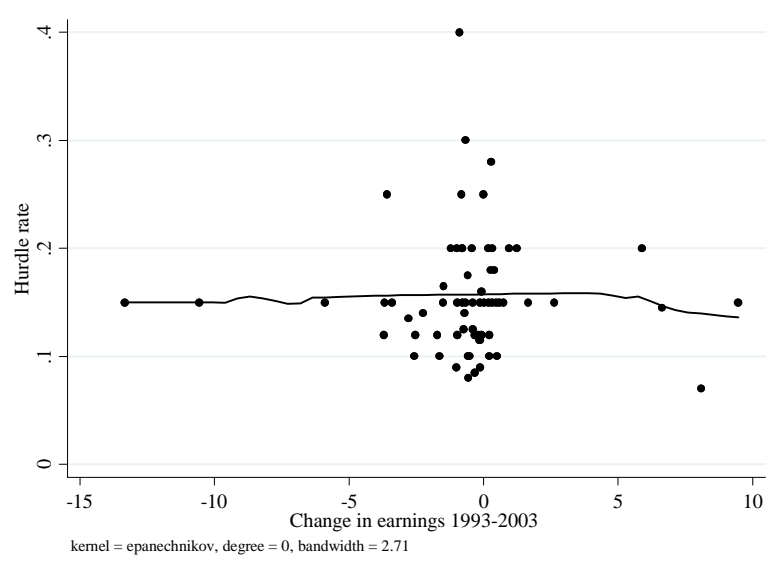


E: Total equity return

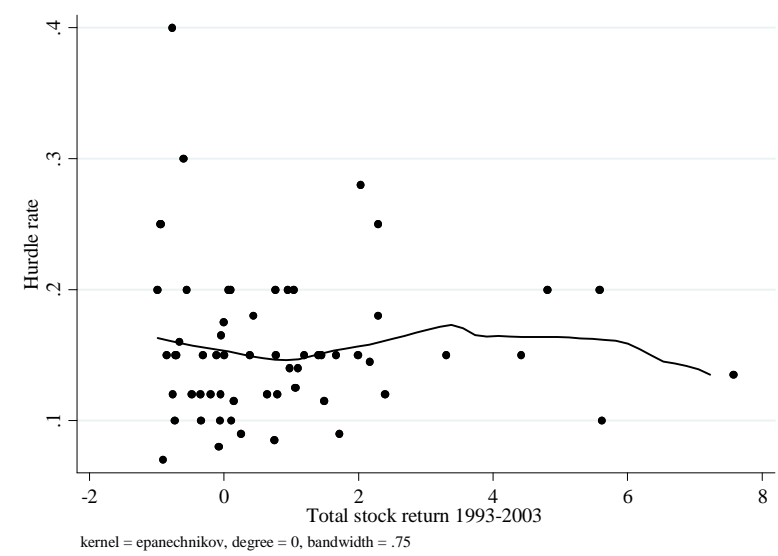

G: Fundamental beta

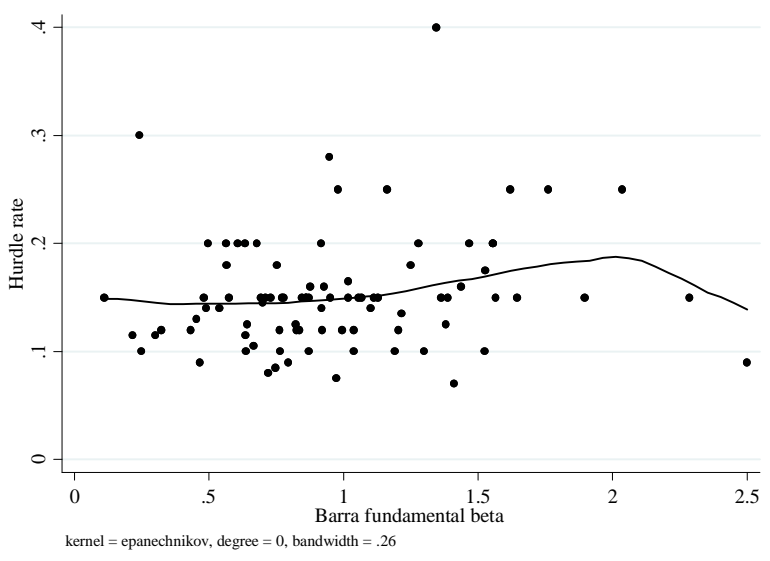

I: Tobin's q

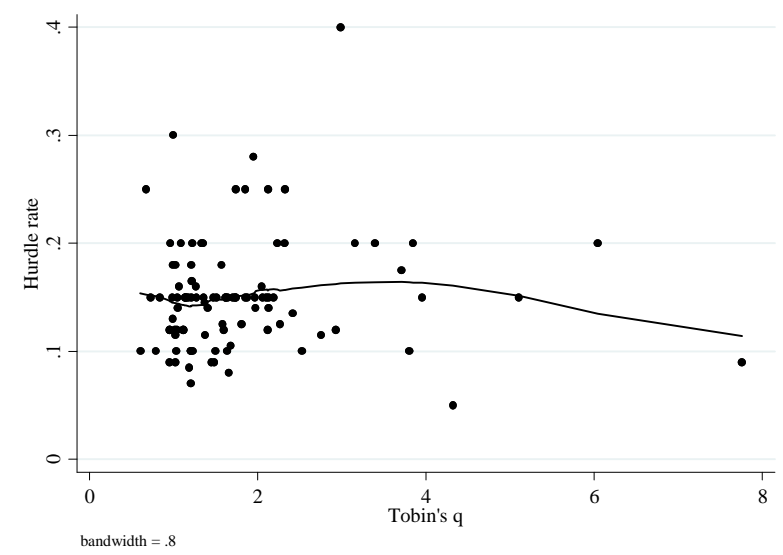

F: Historical beta

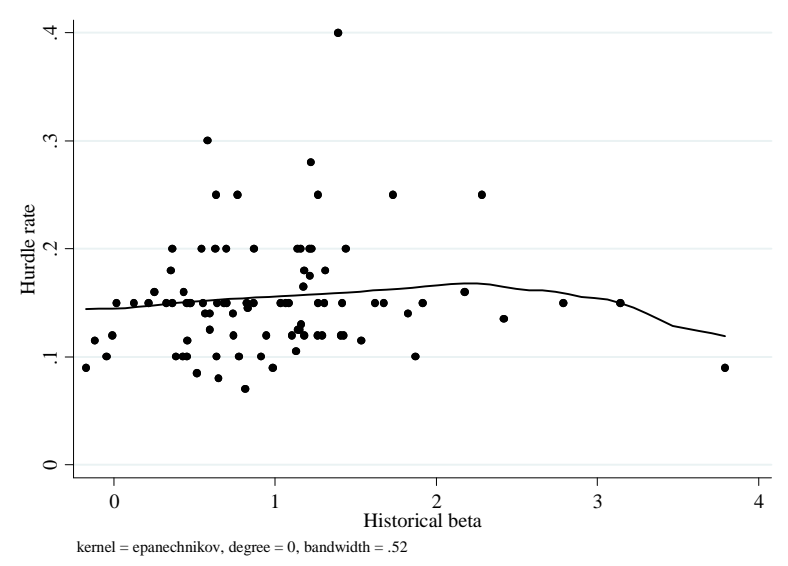

H: Market-to-book ratio

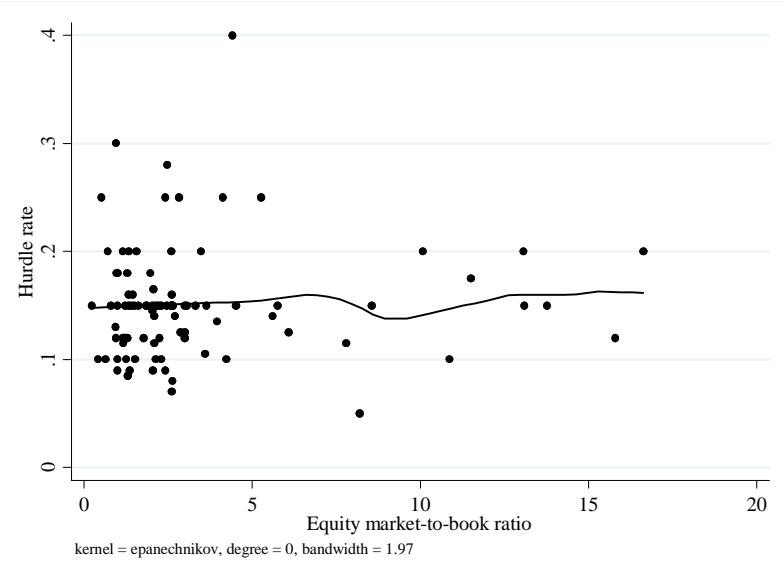

J: Stock turnover rate

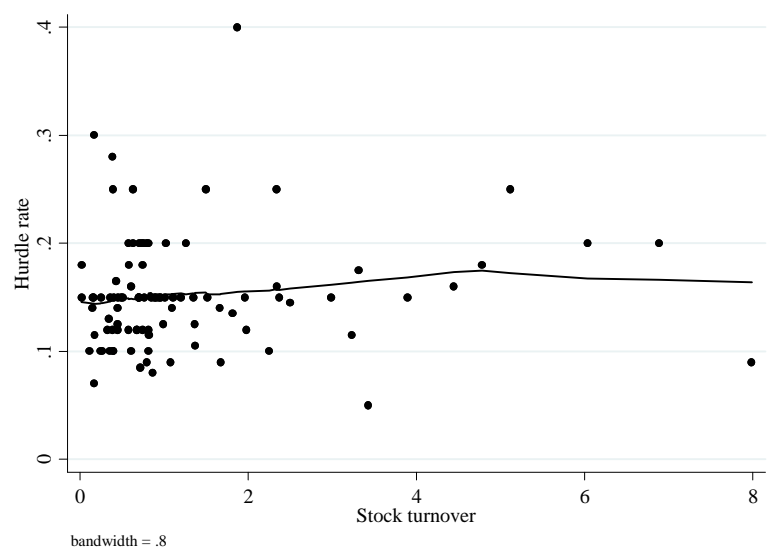




\section{Notes to Figure II:}

The following observations in each Panel have been excluded for the local polynomial fitting and are not shown in the graph:

A: (hurdle rate $0.12, \mathrm{P} / \mathrm{E}$ ratio 467$)$ and $(0.14,479)$. Additionally, the observation with hurdle rate $=0.40$ shown in the graph is excluded when fitting the curve.

B: (hurdle rate 0.15 , dividend payout ratio -2.8).

C: (hurdle rate 0.20 , current ratio 25.2$)$. Additionally, the observation $(0.40,9.7)$ is shown in the graph but excluded when fitting the curve.

E: (hurdle rate 0.15 and total equity return 11.7$)$ and $(0.09,82.5)$.

$\mathrm{H}$ : Negative ratios and ratios larger than 20: (WACC equivalent hurdle rate 0.20 and equity market-tobook ratio 25.6) and $(0.14,-14.6)$. 


\section{Figure 3: What self-reported hurdle rate represents.}

A total of 117 firms responded to the question what the firm's hurdle rate represents (Panel A). The eleven firms that explicitly indicate that they add a premium to the weighted average cost of capital (WACC) to assess their hurdle rate are included in the category WACC. Panel B shows summary statistics of self-reported hurdle rates. The hurdle rates represent the nominal rate that the company has used for a typical project during the previous two years. Self-reported hurdle rates that represent the cost of levered or unlevered equity are converted to their weighted average cost of capital (WACC) equivalents (see Appendix A for details) and firms in the "other" category are dropped from the sample. We report the hurdle rates for the remaining 101 firms.

Panel A

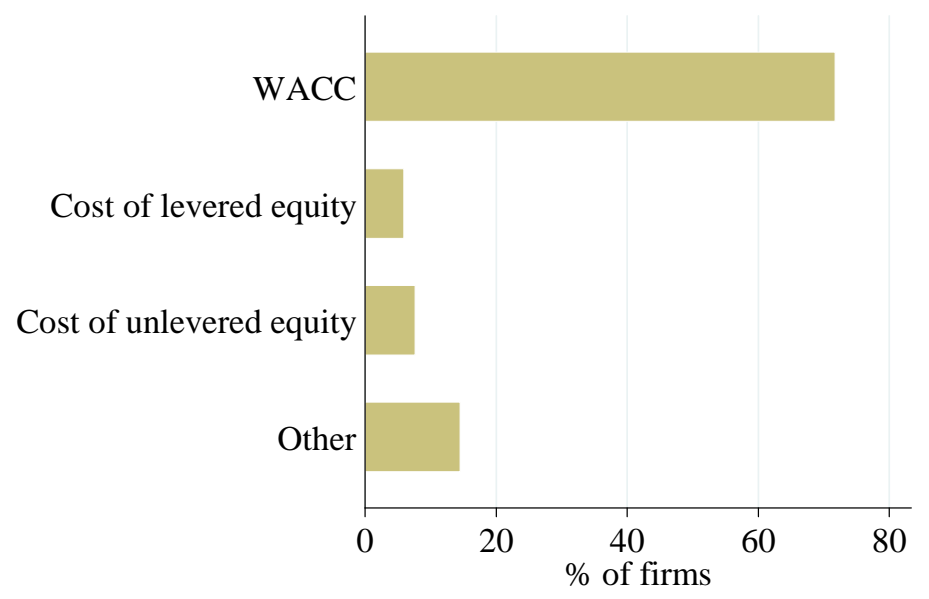

Panel B

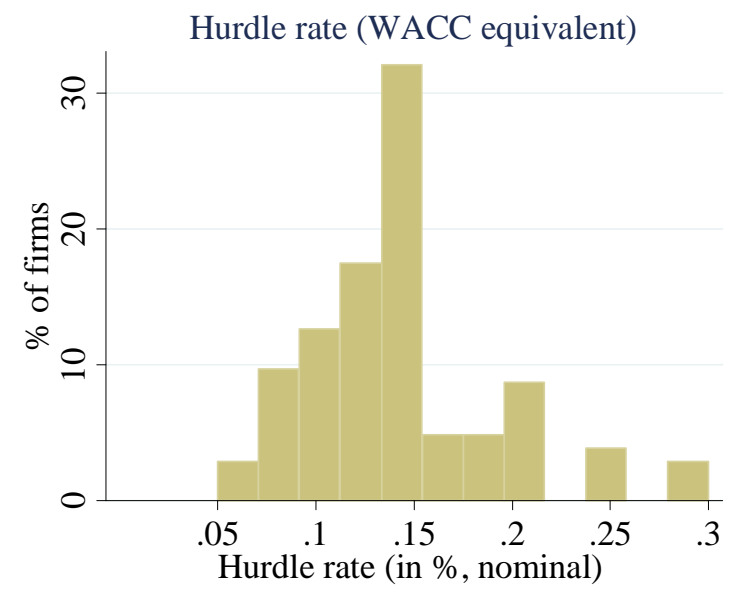


Figure 4: Comparison of the predictions of the full model with self-reported hurdle rates.

Panel A compares predicted hurdle rate from the full model on the horizontal axis with self-reported hurdle rates shown on the vertical axis. Panels $\mathrm{B}$ and $\mathrm{C}$ decompose the predicted values in two components: Predicted WACC against the WACC $=$ hurdle rate - predicted premium and predicted premium against premium $=$ hurdle rate - computed WACC. The solid line in all three panels is the 45degree line.

Panel A

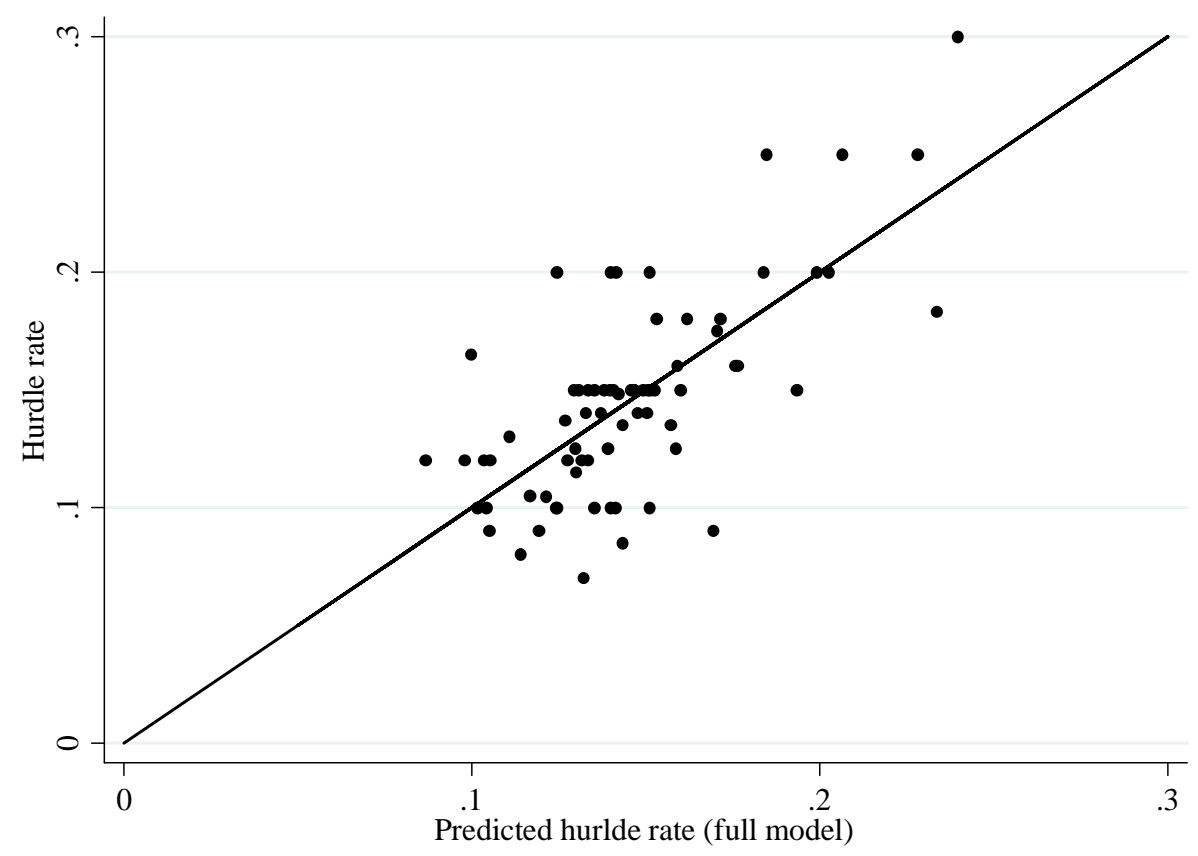

Panel B

Panel C
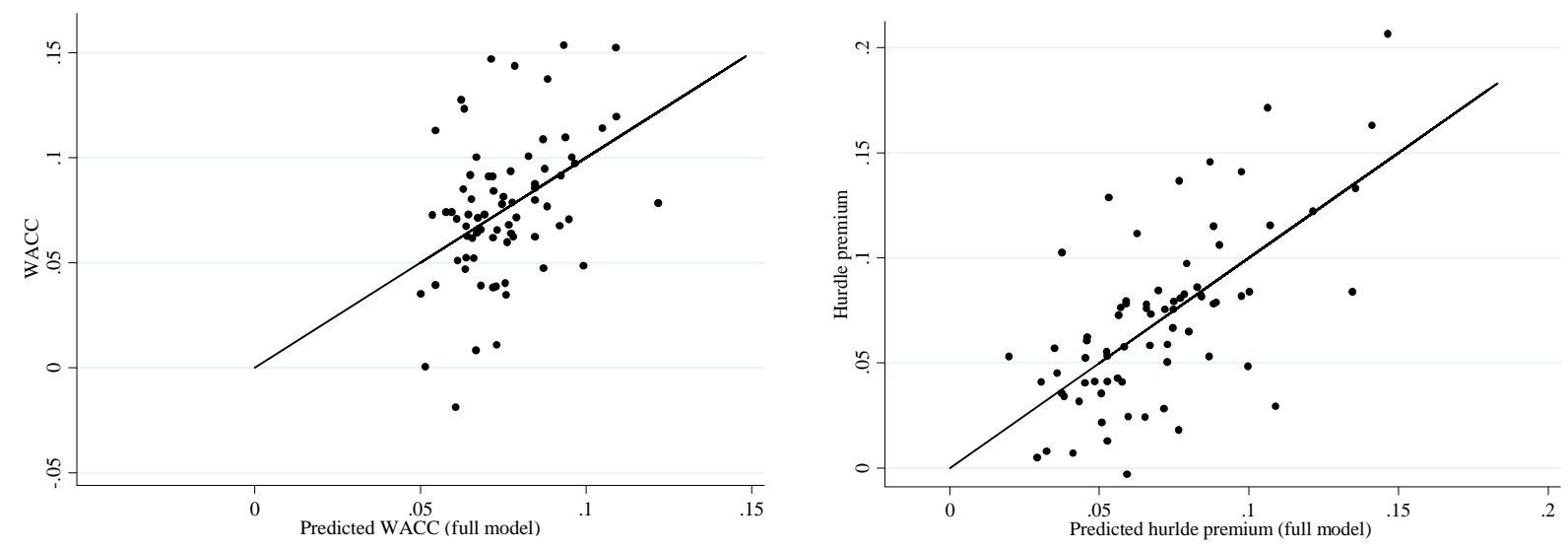
Figure 5: Relationship between hurdle rates and WACC.

The two scatter plots show predicted hurdle rates when using WACC plus a constant (Model 1 in Table VI). Panel A uses the implied equity premium of 3.8\% and Panel B assumes an equity premium of 6.6\% based on a historical average from Ibboston (2004).

Panel A

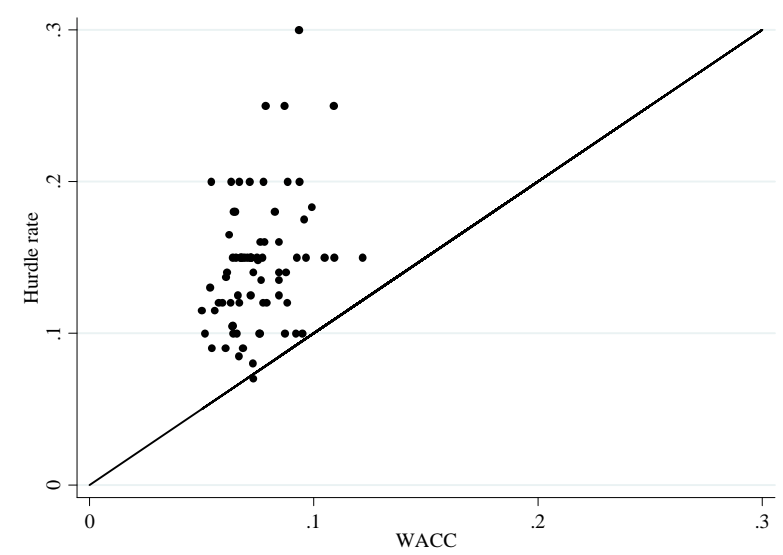

Panel B

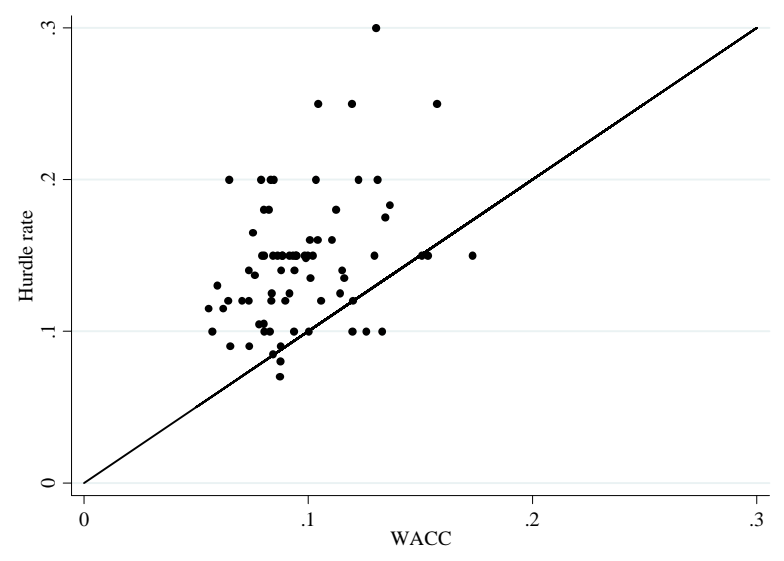

